\title{
LAETRILE: STATUTORY AND CONSTITUTIONAL LIMITATIONS ON THE REGULATION OF INEFFECTIVE DRUGS
}

\section{INTRODUCTION}

The promotion of fraudulent and ineffective cancer remedies presents a continuing challenge to the medical establishment ${ }^{1}$ and the public authorities charged with regulating various aspects of health care. Despite the imposition of governmental restrictions on the advertising and marketing of health care products, cancer patients, due to their vulnerability to exploitation and serious physical harm, have failed to benefit fully from the regulation of drug production and distribution.' Controversy during the 1970's has focused on laetrile, ${ }^{3}$ also known as amygdalin or vitamin $B_{17},{ }^{4}$ a substance allegedly effective for the treatment of cancer..$^{5}$

1 See 42 Fed. Reg. 39,767, 39,795-96 (1977). See also notes 208-11 infra \& accompanying text.

2 See Janssen, Cancer Quackery: Past and Present, FDA ConsuMer, July-August 1977, at 27; Comment, California Cancer Quack Laws: The Best Is None Too Good, 40 S. CAL. L. Rev. 384 (1967) [hereinafter cited as Quack Laws].

3 Laetrile, or amygdalin, is a member of the chemical nitrilosides group. It occurs naturally in the pits of apricots, peaches, bitter almonds, and in other plant materials. The substance can be processed into tablets or liquids used for injections. See Lewis, Laetrile, W.J. MED., July 1977, at 55; 42 Fed. Reg. 10,066-67 (1977).

Although proponents of laetrile claim that apricot extracts were used for health care by ancient civilizations and nineteenth century European physicians, the modern purified form of laetrile was developed by Ernst T. Krebs, Jr., a California biochemist, in 1952. Krebs manufactured and prescribed his treatment privately, and actively promoted its use by cancer patients. See [1978] Food Drug Cos. L. Rep. (CCH) If 42,295; 42 Fed. Reg. 39,767, 39,788 (1977). Krebs' initiatives aroused the concern of the California medical establishment, but no formal action was taken against the prescription of laetrile until the California legislature passed the "Cancer Quackery" law in 1959, CaL. HeALTH \& SAFETY CODE $\$ 1707.1$ (West 1970). This Act prohibits the sale, prescription, and use of any substance for the treatment of cancer unless it is approved for marketing by the FDA or the State Board of Health. The use of laetrile was banned pursuant to the statute in September 1963 after a review of case histories from several states and foreign countries. $17 \mathrm{CAL}$. AD. CodE $\$ 10400.1$ (1963). See generally Quack Laws, supra note 2.

4 M. Culbert, Vitanon B 17, at 53 (1974). A number of courts have equated laetrile and amygdalin in their decisions. See United States v. Spectro Foods Corp., 544 F.2d 1175, 1178 n.I (3d Cir. 1976); Rutherford v. United States, 438 F. Supp. 1287, 1295 n.17 (W.D. Okla. 1977), aff'd as modified, No. 77-2049 (10th Cir. July 10, 1978), petition for cert. filed, 47 U.S.L.W. 3278 (U.S. Oct. 10, 1978) (No. 78605); United States v. General Research Laboratories, 397 F. Supp. 197, 198 (C.D. Cal. 1975).

5 Proponents have made a variety of medical claims for laetrile, including the prevention and treatment of cancer, facilitation of other types of cancer therapy, relief of pain, reduction of odor and blood pressure, treatment of sickle cell anemia and parasitic diseases, and regulation of intestinal flora. 42 Fed. Reg. 39,767, 39,772-73 (1977). 
Until recently, laetrile was an unapproved "new drug" under the regulations of the Food and Drug Administration ("FDA"), and could not be manufactured, sold, or distributed in interstate commerce. $^{6}$ The federal ban on laetrile forced its supporters to consider three courses of action. First, thousands of cancer patients avoided the prohibition by purchasing the drug illegally or by seeking laetrile treatments in other countries. ${ }^{7}$ Second, an organized laetrile lobby sought political support for a relaxation of the ban. These efforts occasionally were successful; seventeen states have legalized the prescription and use of laetrile as a cancer treatment within their respective borders. ${ }^{8}$ Third, laetrile supporters attacked the validity of the FDA's ban, on both statutory and constitutional grounds, in two types of judicial proceedings: criminal actions brought by federal authorities to enforce the ban, ${ }^{8}$ and individual suits seeking injunctive relief to obtain laetrile for personal use. ${ }^{10}$ This Comment will focus upon the third course of

6 [1978] Food Drug Cos. L. Rep. (CCH) \4 42,295.

7 See Am. Med. News, December 19, 1977, at 11, col. 4; N.Y. Times, Sept. 3, 1975, at 36, col. 3 (letter to the editor from Dean Burk and laetrile supporters).

8 [1978] Food Drug Cos. L. Rep. (CCH) I 42,292 . The 17 states that have legalized laetrile include Alaska, Arizona, Delaware, Florida, Idaho, Illinois, Indiana, Kansas, Louisiana, Maryland, Nevada, New Hampshire, New Jersey, Oklahoma, Oregon, Texas, and Washington. Pro-laetrile campaigns failed, however, in 14 states in 1978 as a result of legislative opposition or gubernatorial vetoes. Id.

9 The FDA takes legal action against drug companies that manufacture laetriletype bealth products, on the grounds that the seized products are misbranded, poisonous, or unapproved for distribution in interstate commerce. See, e.g., United States v. Articles of Food \& Drug, 441 F. Supp. 772 (E.D. Wisc. 1977) (upholding an injunction prohibiting defendant manufacturer from producing or distributing laetrile); United States v. Spectro Foods Corp., Civ. No. 76-101 (D.N.J. March 4), aff'd in part, rev'd in part, 544 F.2d 1175 (3d Cir. 1976); United States v. General Research Laboratories, 397 F. Supp. 197 (C.D. Cal. 1975). Individuals have also been prosecuted for conspiracy to smuggle laetrile and for illegal importation of the drug. See, e.g., United States v. Turner, 558 F.2d 46 (2d Cir. 1977); United States v. Westover, 511 F.2d 1154 (9th Cir.), cert. denied, 422 U.S. 1009 (1975); Hanson v. United States, 417 F. Supp. 30 (D. Minn.), affd, 540 F.2d 947 (8th Cir. 1976). Although they are in the minority, some courts have responded leniently to laetrilerelated prosecutions. See, e.g., Millet, Pit \& Seed Co., Inc. v. United States, 436 F. Supp. 84 (E.D. Tenn. 1977) (apricot kernels held to be food rather than a drug); People v. Richardson, Civ. No. 41953-C (Cal., Berkeley-Albany Mun. Ct., May 8, 1974) (case against physician dismissed for inadequate evidence of intent to treat cancer); In re Jones, No. D-1509 (Cal., Board of Medical Ezaminers, November 26, 1975) (doctor on probation for using laetrile in violation of state law).

10 A number of other state and federal courts have struck down the FDA prohibition of laetrile on constitutional grounds or have carved out equitable exceptions. See Rutherford v. United States, 438 F. Supp. 1287 (W.D. Okla. 1977) (district court granted injunctive relief to broad class of cancer patients), affd as modified, No. $77-2049$ (10th Cir. July 10, 1978), petition for cert. filed, 47 U.S.L.W. 3278 (U.S, Oct. 10, 1978) (No. 78-605); Rizzo v. United States, 432 F. Supp. 356 (E.D.N.Y. 1977) (district court granted preliminary injunction to terminal cancer patient, enjoining the FDA from preventing the importation and use of a three month' supply of laetrile by the patient); Carnohan v. United States, Civ. No. 77-0010-GT (S.D. Cal. Jan. 21, 1977) (district court granted preliminary in- 
action, and will examine the merits of the judicial responses to these statutory and constitutional attacks.

The most important recent development in the ongoing laetrile controversy is the decision of the Tenth Circuit in Rutherford $v$. United States ${ }^{11}$ ("Rutherford VI"). The Rutherford VI court permanently enjoined and restrained the Department of Health, Education, and Welfare ("HEW") and the FDA from interfering with

junction to a terminal cancer patient, allowing him to import and use a three-month supply of laetrile); People v. Privitera, 74 Cal. App. 3d 936, 141 Cal. Rptr. 764 (1977) (California statute prohibiting the sale or use of unapproved cancer drugs invaded the patients' and doctors' zones of privacy); Suenram v. Society of Valley Hospital, 155 N.J. Super. 593, 383 A.2d 143 (1977) (court enjoined hospital from interfering with cancer patient's use of laetrile, holding that the patient's right of privacy allowed her to determine her own personal destiny).

11 No. 77-2049 (10th Cir. July 10, 1978), petition for cert. filed, 47 U.S.L.W. 3278 (U.S. Oct. 10, 1978) (No. 78-605). The Rutherford VI decision was the culmination of a series of cases initiated by cancer victim Glen L. Rutherford. In 1975, petitioner Rutherford and other cancer patients initiated an action against the Secretary of HEW in the Federal District Court for the Western District of Oklahoma, seeking an order directing the agency to desist from prohibiting the administration of laetrile. The court granted equitable injunctive relief, holding that plaintiffs had been denied the right to use laetrile without just cause or due process. Rutherford v. United States, 399 F. Supp. 1208 (W.D. Okla. 1975) (Rutherford I), aff'd, remanded on other grounds, 542 F.2d 1137 (10th Cir. 1976), modified on remand, 424 F. Supp. 105 (W.D. Okla.), modified, 429 F. Supp. 506 (W.D. Okla. 1977). The Tenth Circuit upheld the preliminary injunction on appeal, remanding the case to the district court to determine whether the FDA had developed an administrative record adequate to support its prohibition of laetrile. Rutherford v. United States, 542 F.2d 1137 (10th Cir. 1976) (Rutherford II), modified on remand, 424 F. Supp. 105 (W.D. Okla.), modified, 429 F. Supp. 506 (W.D. Okla. 1977). On remand, the district court held that in view of the absence of an administrative record, the determination that laetrile was a prohibited "new drug" could not stand, and remanded the case to the FDA for compilation of an administrative record to support its determination by substantial evidence. Rutherford v. United States, $424 \mathrm{~F}$. Supp. 105 (W.D. Okla.) (Rutherford III), modified, 429 F. Supp. 506 (W.D. Okla. 1977). The Rutherford III court also certified plaintiffs' suit as a class action, and continued to enjoin the FDA from preventing plaintiffs' importation or interstate transportation of laetrile for their own use.

Plaintiffs next moved to clarify their class action by requesting an extension of the injunction to all cancer victims and their spouses. Rutherford v. United States, 429 F. Supp. 506 (W.D. Okla. 1977) (Rutherford IV). The district court declined to broaden the injunction, but it certified that all patients declared by a practicing physician to be terminally ill were entitled to injunctive relief.

In compliance with these decisions, the FDA conducted a rulemaking proceeding in May 1977 on the regulatory status of laetrile. After hearing oral and written testimony on the issues, the Commissioner concluded that laetrile was an unapproved new drug under the provisions of the Food, Drug, and Cosmetics Act, and therefore was barred from interstate commerce. 42 Fed. Reg. 39,767 (1977). The Commissioner's action was declared unlawful and vacated on judicial review in Rutherford v. United States, 438 F. Supp. 1287 (W.D. Okla. 1977) (Rutherford V), aff'd as modified, No. 77-2049 (10th Cir. July 10, 1978), petition for cert. filed, 47 U.S.L.W. 3278 (U.S. Oct. 10, 1978) (No. 78-605). The district court found that the FDA's determination was not supported by substantial evidence, and ruled that laetrile was exempt from the new drug requirements of the statute. The court also held that the prohibition of laetrile use violated the fundamental right of privacy of cancer patients, and accordingly granted injunctive relief to "[any] person who is, or believes he is, suffering from the disease." Id. 1301. The Government sought review of the district court's decision in the Rutherford VI adjudication. 
the procurement and personal use of laetrile by medically certified terminally-ill cancer patients. ${ }^{12}$ The court also ordered the FDA to promulgate regulations "with all due dispatch" for the use of laetrile by terminal patients, as if the drug had been found safe and effective for such patients, and in so doing interfered with the FDA's listing of laetrile as an unapproved new drug. ${ }^{13}$ In reaching this result, the court determined that the FDA's "safety" and "effectiveness" requirements for new drug approval are inapplicable to terminally-ill cancer patients who desire to take the drug intravenously. ${ }^{14}$

By choosing to resolve the case through the creation of a statutory exception for terminal patients, the Tenth Circuit sidestepped two important issues. First, the court ignored the underlying statutory question of laetrile's general status as an unapproved new drug governed by the FDA. In contrast, the district court in Rutherford v. United States ${ }^{15}$ ("Rutherford" V) had held that laetrile was exempted from regulation by a statutory grandfather clause.

Second, the Rutherford VI opinion failed to address the constitutionality of the laetrile ban. The Rutherford $\mathrm{V}$ court, in addition to its statutory holding, had ruled that federal regulation of laetrile violated the privacy rights of cancer patients. ${ }^{16}$ The court enforced these constitutional rights by granting injunctive relief to any person "who is, or believes he is, suffering from the disease." 17 Similarly, in People v. Privitera, ${ }^{18}$ the California Court of Appeals reversed a conviction for selling laetrile, an illegal unapproved cancer treatment under state law, ${ }^{19}$ on the ground that the statute in question invaded the privacy rights of both patients and doctors as protected by the state ${ }^{20}$ and federal constitutions.

This Comment will examine the statutory and constitutional status of the laetrile regulations in light of these recent developments. It begins with an examination of the policies and procedures

12 No. 77-2049, slip op. at 6 (10th Cir. July 10, 1978), petition for cert. filed, 47 U.S.L.W. 3278 (U.S. Oct. 10, 1978) (No. 78-605).

13 Id.

$14 \mathrm{Id} .5$.

15438 F. Supp. 1287 (W.D. Okla. 1977), aff'd as modified, No. 77-2049 (10th Cir. July 10, 1978), petition for cert. filed, 47 U.S.L.W. 3278 (U.S. Oct. 10, 1978)

(No. 78-605).

16 Id. 1301.

17 Id. 1298-1301.

1874 Cal. App. 3d 936, 141 Cal. Rptr. 764 (1977).

19 CaL. Health \& SAFETx Code $\$ 1707.1$ (West 1970).

20 The California Constitution guarantees a right of privacy to Californians. CAL. Const. art. $1, \S 1$. 
of the Federal Food, Drug, and Cosmetic Act (the "Act"). ${ }^{21}$ Following this background discussion, the Comment applies the statute to laetrile, concluding that laetrile is properly classified as an unapproved new drug under the Act, and is legitimately barred from interstate commerce. An in-depth criticism of the Rutherford VI decision follows, in which the Comment questions the assumptions of the Tenth Circuit and concludes that the terminal patient exemption is not statutorily justified. The focus of the Comment then shifts to the constitutional considerations implicit in laetrile control. The privacy rights of cancer victims are examined in light of recent cases on the subject, and are balanced against the government's interest in maintaining the current regulatory procedures. The primary governmental concerns-protecting public safety, preventing the delay of effective treatment, and preventing the deception of the public-are found to be sufficiently compelling to justify the regulation of laetrile for all classes of cancer patients. Finally, suggested alternatives to the current procedures are examined, but are dismissed as inadequate to further these compelling governmental interests.

\section{Statutory Boundaries of FDA Drug Regulations}

Initially, the validity of the laetrile prohibition depends upon the applicability of the Federal Food, Drug, and Cosmetic Act (the "Act") ${ }^{22}$ to the drug. If, as laetrile supporters claim and the Rutherford $\mathrm{V}$ court held, ${ }^{23}$ the drug is not banned by the Act, there is no need to consider the constitutional implications of the prohibition. In resolving the issue of statutory construction, three essential questions must be answered: (1) What is the framework of the Act? (2) How does laetrile fit within this framework in light of the current scientific data? and (3) Does the Act apply to all classes of patients, or is there an exemption for the terminally ill?

\section{A. The Statutory Framework}

\section{Congressional Policy}

The first congressional effort to regulate drugs on a national scale was the Food and Drug Act of 1906.24 This legislation set

2121 U.S.C. $\$ \$ 301-392$ (1976).

22 Id.

23 Rutherford v. United States, 438 F. Supp. 1287 (W.D. Okla. 1977), aff'd as modified, No. 77-2049 (10th Cir. July 10, 1978), petition for cert. fled, 47 U.S.L.W. 3278 (U.S. Oct. 10, 1978) (No. 78-605).

$24 \mathrm{Ch} .3915$, 34 Stat. 768 (1906) (repealed by the Federal Food, Drug, and Cosmetic Act, ch. 675, $\$ 902$ (a), 52 Stat. 1040, 1059 (1938)). 
purity standards for drugs transported in interstate commerce ${ }^{25}$ and required all manufacturers to list the full contents of a product on its label. ${ }^{26}$ Although Congress also sought to prevent false therapeutic claims by manufacturers and promoters through amendments to the 1906 Act in 1912, ${ }^{27}$ the 1906 Food and Drug Act proved ineffective in establishing pre-marketing or post-marketing standards for drug safety and efficacy. ${ }^{28}$

The 1938 Food, Drug, and Cosmetic Act ${ }^{29}$ replaced the 1906 Act, and attempted to establish these standards. It created a new application ("NDA") process for pre-marketing review of drug safety ${ }^{30}$ and prohibited the distribution of adulterated, impure, or misbranded drugs and devices. ${ }^{31}$ These regulations were to be enforced by a Food and Drug Administration, empowered to seize illegal products, ${ }^{32}$ initiate criminal proceedings, ${ }^{33}$ or seek injunctive remedies. ${ }^{34}$ The legislation failed, however, to police drugs effectively or to establish fair procedures and prices in the drug industry. ${ }^{35}$

Despite the inadequacies of this legislation, there was significant resistance to changes in the Act, until the thalidomide crisis in Europe provided the necessary impetus for unanimous congressional action on drug reform legislation. ${ }^{36}$ The ensuing 1962 Kefauver-

25 Id. $\$ 7,34$ Stat. at 769 .

28 Id. $\$ 8,34$ Stat. at 770 .

27 Act of Aug. 23, 1912, ch. 352, 37 Stat. 416 (1912) (repealed by the Federal Food, Drug, and Cosmetic Act, ch. 675, $\$ 902$ (a), 52 Stat. 1040, 1059 (1938)).

28 See Janssen, supra note 2, at 28; Note, Drug Efficacy and the 1962 Drug Amendments, 60 GEo. L.J. 185, 186 (1971).

29 Food, Drug, and Cosmetic Act of 1938, ch. 675, 52 Stat. 1040 (1938) (currently codified at 21 U.S.C. $\$ \$ 301-392$ (1976)).

30 Id. $\$ \$ 201$ (p) \& 505, 52 Stat. at 1041 \& 1052. Under the 1938 Act, the effectiveness of a new drug was not a matter for agency concern. A new drug application automatically became effective within 60 days unless the Secretary of Agriculture refused to approve it due to inadequate evidence of safety. Id. $\$ \$ 505$ (c) \& (d), 52 Stat. at 1052 (1938). The present version requires the Secretary of HEW to approve the application, deny it, or give notice of a hearing within 180 days of filing. 21 U.S.C. $\$ \$ 355$ (c) \& (d) (1976).

31 Id. $\$ 501,52$ Stat. at 1049 (adulterated drugs and devices); $\$ 502$, 52 Stat. at 1050 (misbranded drugs and devices).

32 Id. $\$ 304,52$ Stat. at 1044 .

33 Id. $\S 303,52$ Stat. at 1043.

34 Id. $\$ 302,52$ Stat. at 1043.

35 The problems of federal drug regulation were publicized by the "Kefauver Hearings" of 1960 and 1961. This investigation into drug industry practices and prices was carried out by the Antitrust and Monopoly Subcommittee of the Senate Judiciary Committee. See S. Rep. No. 1744, 87th Cong., 2d Sess. 11 [hereinafter cited as 1962 Senate Report, reprinted in [1962] U.S. Code Cong. \& AD. News $2884,2887$.

36 Id. at 40, [1962] U.S. Code CONG. \& AD. News at 2905. The Judiciary Committee initially made significant amendments to the proposed reform legislation, 
Harris Drug Amendments ${ }^{37}$ significantly altered the scope and substance of the federal regulations. First, the amendments initiated the requirement that new drugs must be scientifically established as safe and effective prior to marketing. ${ }^{38}$ The Senate Committee noted that " $[t]$ he only sound standard is that a drug must be safe and that there must be substantial evidence showing that the drug has produced the specific physiological effects claimed for it." 30 This standard reflected the views of several senators on the committee that "the marketing of a safe but ineffective drug may well be positively injurious to the public health. When an ineffective drug is prescribed, it is usually in place of an older but effective drug." 40 Second, the new Act amended the new drug application process ${ }^{41}$ and created procedures for the post-marketing withdrawal of unsafe and ineffective drugs. ${ }^{42}$ Third, the statute adopted high scientific standards for testing and a strict legal standard of proof. 43 The intended impact of these changes was "to strengthen the laws designed to keep unfit drugs off the market in the first instance and speed their removal should they reach the market." 44

\section{New Drug Marketing Procedures}

The crucial statutory issue confronting laetrile supporters is whether laetrile can be categorized as a "new drug" within the meaning given that term by the 1962 Food, Drug, and Cosmetic

but reinstated the more stringent provisions after the thalidomide incident. See Drug Amendments, [1962] Cong. Q. Acm. 197-98.

37 Drug Amendments of 1962, Pub. L. No. 87-781, 76 Stat. 780 (1962) (codified at 21 U.S.C. $\$ \$ 301-392(1976))$.

3821 U.S.C. $\$ 355(\mathrm{e})(1976)$.

391962 Senate Report, supra note 35, at 9, [1962] U.S. Code Cong. \& Ad. News at 2892.

40 Id. at 37, U.S. Code Cong. \& AD. News at 2902 (views of Senators Kefauver, Carroll, Dodd, Hart, and Long).

41 The present application process consists of three steps. Initially, a drug's sponsor must conduct animal studies or collect data and file a "Notice of Claimed Investigational Exemption for a New Drug" (IND) with the FDA. 21 U.S.C. $\$ 355$ (i) (1) (1976). If these studies demonstrate that the new drug is reasonably safe, the FDA will approve the IND and permit the sponsor to distribute the drug for investigational use on humans. Id. $\$ 355(i)$. After the completion of these tests, the sponsor files a New Drug Application setting forth all available information on the safety and effectiveness of the drugs. Id. $\$ 355(\mathrm{~b})$. Approval of this application certifies the drug for commercial marketing and use.

42 Id. $\$ 355(\mathrm{e})$.

$43 \mathrm{Id}$. $\$ 355(\mathrm{~d})$. This section requires that all applications be supported by "substantial evidence," defined as "evidence consisting of adequate and well-controlled investigations, including clinical investigations, by experts qualified by scientific training and experience to evaluate the effectiveness of the drug involved . . .." 441962 Senate Report, supra note 35, at 8, [1962] U.S. Code Cong. \& Ad. NEws at 2884. 
Act, and therefore marketed only after filing and approval of a new drug application. The resolution of this question depends upon judicial construction of the definitional standards of the Act and the "grandfather clause" exemptions it provides for certain products.

\section{a. Definitional Standards}

The 1962 Drug Amendments define a "new drug" as follows: "Any drug . . . the composition of which is such that such drug is not generally recognized, among experts qualified by scientific training and experience to evaluate the safety and effectiveness of drugs, as safe and effective for use under the conditions prescribed, recommended, or suggested in the labeling." 45 Under this definition, a manufacturer must show by substantial evidence ${ }^{48}$ that the "drug" ${ }^{77}$ in question is generally recognized as safe and effective in order to avoid filing a detailed new drug application ${ }^{48}$ and satisfying its strict standard of proof. This process is not directly concerned with the actual safety and effectiveness of the product; ${ }^{49}$ instead, the focus is on the general perception of the product among knowledgeable members of the scientific and medical communities.

4521 U.S.C. $\$ 321(\mathrm{p})(1)$ (1976) (original version at ch. 675 , 52 Stat. 1040 (1938)) (emphasis added).

46 See Weinberger v. Hynson, Westcott, \& Dunning, Inc., 412 U.S. 609, 617 (1973); North Am. Pharm., Inc. v. Dep't of HEW, 491 F.2d 546, 551 (8th Cir. 1973).

47 The status of a substance as a drug depends upon its intended use. Any article "intended for use in the diagnosis, cure, mitigation, treatment, or prevention of disease in man or other animals" is a drug within the meaning of the Act. 21 U.S.C. $\$ 321(\mathrm{~g})(1)(\mathrm{B})$ (1976) (original version at ch. $675, \$ 20 \mathrm{I}(\mathrm{g})(1)(\mathrm{B}), 52$ Stat. 1040 (1938)). As a result, the fact that a product is technically a food or cosmetic does not mean that it cannot also be a drug. If the product is labeled, advertised, or promoted as a drug, it may be inferred that it is intended to be a drug. See United States v. Nutrition Serv., Inc., 227 F. Supp. 375, 380-81 (W.D. Pa. 1964), aff'd, 347 F.2d 233 (3d Cir. 1965).

48 An NDA must contain all available information on the drug in question. The submission is specifically required to include the following: a table of contents, a summary, favorable and unfavorable evidence of safety and effectiveness, copies of all labeling, a list of components, a description of manufacturing methods, samples of the drug and its components, and all reports of preclinical investigations. 21 C.F.R. $\$ 314.1$ (1977).

49 See AMP Inc. v. Gardner, 389 F.2d 825, 831 (2d Cir.), cert. denied sub nom. AMP Inc. v. Cohen, 393 U.S. 825 (1968); United States v. Articles of Drug Labeled Colchicine, 442 F. Supp. 1236, 1242 (S.D.N.Y. 1978); National Ethical Pharm. Ass'n v. Weinberger, 365 F. Supp. 735, 736-37 (D.S.C. 1973), aff'd, 503 F.2d 1051 (4th Cir. 1974); United States v. Article of Drug "Mykocert," 345 F. Supp. 571, 574 (N.D. Ill. 1972). Because actual safety and effectiveness are not at issue, a determination that a product is a new drug does not necessarily mean that it is unsafe or ineffective. See United States v. 1,048,000 Capsules, More or Less, "Afrodex," 494 F.2d 1158, 1160 (5th Cir. 1974). 
Several questions, implicit in the statutory definition, remain to be answered: (1) What institutional authority determines a product's status as a new drug? (2) What degree of expert consensus is sufficient to demonstrate general recognition? (3) Which research procedures are acceptable bases for general recognition? (4) What factors may be considered as evidence of a lack of general recognition?

The FDA initially determines a particular drug's status as a "new drug" within the meaning of the Act.50 This allocation of authority to an administrative agency reflects Congress's desire to have the complex technical and scientific issues of drug regulation decided by experts rather than by the courts. ${ }^{51}$ Although their jurisdiction is limited at the outset, federal courts may review a "new drug" order pursuant to the terms of the Administrative Procedure Act ${ }^{52}$ or the general equity powers of the court. ${ }^{53}$ The reviewing court is not allowed to substitute its own factual views for those of the agency, but it can engage in a substantial inquiry that is both "searching and careful." 51

The courts have not been consistent in their interpretation of the "general recognition" standard. Originally, several courts held that the existence of any genuine difference of opinion sufficed to demonstrate that the drug in question was not generally recognized as safe and effective..5 This rule, however, has been criticized as requiring unanimous, rather than general, recognition. ${ }^{56}$ Thus, the current view is that "general" should be accorded its commonsense

50 See Weinberger v. Bentex Pharm., Inc., 412 U.S. 645, 652-54 (1973); Weinberger v. Hynson, Wescott \& Dunning, Inc., 412 U.S. 609, 626 (1973); CIBA Corp. v. Weinberger, 412 U.S. 640, 643 (1973).

51 See id. 643-44; Hanson v. United States, 417 F. Supp. 30, 37 (D. Minn. 1976); Lemmon Pharm. Co. v. Richardson, 319 F. Supp. 375, 377 (E.D. Pa. 1970). One writer has suggested that an individual should be able to seek immediate relief in court rather than undergoing a lengthy FDA proceeding in cases in which there is a dispute over a drug's safety and the individual's situation is so extreme that it outweighs the state's interest in safety and effectiveness. Comment, Government Regulation of Health Care Drugs of Questionable Efficacy, I4 SAN DIEgo L. Rev. 378, 403-04 (1977) [hereinafter cited as Questionable Drugs].

525 U.S.C. $\$ \$ 701-706$ (1976).

53 See Abbott Laboratories v. Gardner, 387 U.S. 136 (1967). Any citizen aggrieved by an order of the Commissioner may equitably test the legality of that order in court.

54 Citizens to Preserve Overton Park, Inc. v. Volpe, 401 U.S. 402, 416 (1971).

55 Merritt Corp. v. Folsom, 165 F. Supp. 418, 421 (D.D.C. 1958). See also United States v. Article of Drug Labeled "Furestrol Vaginal Suppositories," 294 F. Supp. 1307, 1311 (N.D. Ga. 1968), aff'd, 415 F.2d 390 (5th Cir. 1969); United States v. 354 Bulk Cartons . . . Trim Reducing-Aid Cigarettes, 178 F. Supp. 847, 853 (D.N.J. 1959).

50 See, e.g., United States v. An Article of Drug "Bentex Ulcerine," 469 F.2d 875,879 (5th Cir. 1972), cert. denied, 412 U.S. 938 (1973). 
meaning. As one court explained: "There is nothing in the statute to indicate that Congress intended 'generally recognized' in other than its commonly understood meaning. The adverb, 'generally,' is defined, inter alia, to mean, 'In general; extensively, though not universally; most frequently, but not without exception; ***'." 57 Whichever standard is applied, however, it is clear that general recognition requires more than a mere preponderance of the available evidence.

Expert opinions regarding a drug's safety or effectiveness cannot be based on clinical impressions or uncontrolled experiments; ${ }^{58}$ the substantial evidence requirement ${ }^{59}$ of the Act requires wellcontrolled clinical investigations, based upon recognized scientific principles. Therefore, only studies that meet designated scientific standards, as promulgated by the Secretary of $\mathrm{HEW},{ }^{60}$ are acceptable in determining whether evidence exists to support a claim of general recognition. ${ }^{61}$

The performance of the requisite studies and the collection of favorable data does not always ensure that the FDA will find the drug in question to be generally recognized as safe and effective; the presence of any of the following competing factors may serve to overcome the favorable inferences that normally attend compliance with the requirements of the Act. First, the absence of published medical or scientific literature relating to the drug's usage is considered to be damaging evidence, ${ }^{62}$ because studies submitted to

$57 \mathrm{Id}$. (quoting United States v. 7 Cartons, More or Less, "Ferro-Lac Swine Formula Concentrate (Medicated)," 293 F. Supp. 660, 662-63 (S.D. Ill. 1968), modified on other grounds, 424 F.2d 1364 (7th Cir. 1970)). Many courts have applied this standard. See, e.g., AMP Inc. v. Gardner, 389 F.2d 825, 831 (2d Cir.), cert. denied sub nom. AMP Inc. v. Cohen, 393 U.S. 825 (1968); United States v. X-Otag Plus Tablets, 441 F. Supp. 105, 110 (D. Colo. 1977); United States $v$. 1,048,000 Capsules, More or Less, "Afrodex," 347 F. Supp. 768, 770 (S.D. Tex. 1972), aff'd, 494 F.2d 1158 (5th Cir. 1974). A Senate Report accompanying the 1962 Drug Amendments expressed this interpretation. 1962 SENATE REPORT, supra note 35, [1962] U.S. CODE CONG. \& AD. News 2884. Further, the FDA has also shown a willingness to define "general" as "extensive." See 42 Fed. Reg. 39,767, 39,776 (1977).

58 See Weinberger v. Hynson, Wescott \& Dunning, Inc., 412 U.S. 609, 630 (1973). The absence of laboratory testing, experimentation, and investigation is evidence of a lack of general recognition. United States v. An Article of Drug "Bentex Ulcerine," 469 F.2d 875, 880 (5th Cir. 1972), cert. denied, 412 U.S. 938 (1973); United States v. 14 Cases, More or Less, (Bag) "Naremco Medi-matic," 374 F. Supp. 922,929 (W.D. Mo. 1974).

59 See note 43 supra.

6021 C.F.R. $\$ 314.111(\mathrm{a})(5)$ (1977).

61 See Weinberger v. Hynson, Wescott \& Dunning, Inc., 412 U.S. 609, 629-30 (1973); Sterling Drug Inc. v. Weinberger, 503 F.2d 675, 677 (2d Cir. 1974).

62 See, e.g., Weinberger v. Bentex Pharm., Inc., 412 U.S. 645, 652 (1973); United States v. 41 Cases, More or Less, 420 F.2d 1126, 1130 (5th Cir. 1970); United States v. Articles of Drug Labeled Colchicine, 442 F. Supp. 1236, 1242-43 
scientific publications undergo professional review prior to publication and thus contribute to the circulation of information about the drug. Second, if the composition of a drug or one of its ingredients is unknown, a finding of general recognition will be precluded. ${ }^{63}$ Third, it is significant if a given product is not discussed or used at medical schools. ${ }^{\text {i4 }}$ These and other background factors supplement the required showings of adequate testing and extensive recognition among experts.

\section{b. Grandfather Clause Exemptions}

Another way for a manufacturer to avoid compliance with the new drug application procedures is to establish an exemption for the drug before the FDA ${ }^{65}$ under either of the two grandfather clauses contained in the Act. These clauses permit older drugs to avoid the safety and effectiveness standards of the 1962 Act, provided they meet certain requirements.

The first grandfather clause, the 1938 exemption, provides that no drug shall be deemed a new drug "if at any time prior to June 25, 1938, it was subject to the Food and Drug Act of June 30, 1906, as amended, and if at such time its labeling contained the same representations concerning the conditions of its use." 68 This exemption applies only to drugs that have undergone no change in composition, labeling, or recommended conditions of use. ${ }^{67}$ In addition, a grandfather clause exemption does not shield a drug from other sections of the statute that prohibit the marketing of toxic, harmful, or misbranded products. ${ }^{88}$

(S.D.N.Y. 1978); United States v. X-Otag Plus Tablets, 441 F. Supp. 105, 110 (D. Colo. 1977); United States v. An Article of Drug Labeled "Entrol-C Medicated," 362 F. Supp. 424, 426 (S.D. Cal. 1973), aff'd, 513 F.2d 1127 (9th Cir. 1975).

B3 See United States v. 1,048,000 Capsules, More or Less, "Afrodex," 494 F.2d 1158, 1161 n.2 (5th Cir. 1974); Durovic v. Richardson, 479 F.2d 242, 251 (7th Cir.), cert. denied, 414 U.S. 944 (1973). 1970).

64 Lemmon Pharm. Co., Inc. v. Richardson, 319 F. Supp. 375, 378 (E.D. Pa.

65 The FDA has initial jurisdiction to decide whether a drug is grandfathered under the statute. This FDA decision is reviewable in district court pursuant to the Administrative Procedure Act. See Weinberger v. Bentex Pharm., Inc., 412 U.S. 645, 651-53 (1973); North Am. Pharm., Inc. v. Dep't of HEW, 491 F.2d 546, 549 (8th Cir. 1973). The finding that a particular drug is grandfathered cannot, however, be inferred; the FDA must take affirmative action to ratify any such determination. See Levine, Recent "New Drug" Litigation Involving the "Grandfather Clause" and Hearing Rights, 28 Bus. Law. 769, 777 (1973).

60 21 U.S.C. $\$ 321(p)(1)(1976)$ (original version at ch. $675, \S 201(p)(1)$, 52 Stat. 1041 (1938)).

67 See Rutherford v. United States, 542 F.2d 1137, 1142 (10th Cir. 1976);

42 Fed. Reg. 39,767, 39,788 (1977).

68542 F.2d 1137, 1142 n.4 (10th Cir. 1976). 
The second, 1962, grandfather clause exempts certain drugs otherwise categorized as "new drugs" from meeting the "generally recognized as effective" requirement. The goal of this clause was to ensure a smooth transitional period when the 1962 Amendments became effective. The exemption covers any drug which, on the day immediately preceeding the enactment date of the Amendments, was commercially ${ }^{69}$ used or sold in the United States, was generally recognized as safe by qualified experts, and was not covered by an effective ${ }^{70}$ new drug application. The exemption applies if the drug in question is intended for use under the conditions prescribed ${ }^{71}$ or suggested on previous labeling. ${ }^{72}$

The elaborate requirements of the 1962 exemption make it a difficult one to invoke. A claimant must prove every essential fact ${ }^{73}$ required by the terms of the exemption, because grandfather clause exceptions are strictly construed against the party that invokes their protection. $^{74}$ This high standard of proof also applies to the FDA's procedural guidelines for grandfather clause contentions. Applications for a grandfather clause exemption must conform to a specific

69 The phrase "commercially used or sold" has been interpreted to require that the drug be readily available and broadly distributed in the marketplace. Investigational drugs therefore are excluded from the exemption. See Durovic v. Richardson, 479 F.2d 242, $247-48$ (7th Cir.), cert. denied, 414 U.S. 944 (1973). But see Rutherford v. United States, 438 F. Supp. 1287, 1296 n.21 (W.D. Olda. 1977), aff'd as modified, No. 77-2049 (10th Cir. July 10, 1978), petition for cert. filed, 47 U.S.L.W. 3278 (U.S. Oct. 10, 1978) (No. 78-605).

70 This term includes an application that was once effective; withdrawals only take place at the behest of the FDA. See Weinberger v. Hynson, Westcott \& Dunning, Inc., 412 U.S. 609, 632 (1973); USV Pharm. Corp. v. Weinberger, 412 U.S. 655, 667 (1973). Congressional policy exempts only drugs that never were subject to the new drug provisions of the Act.

71 "Conditions of use include, among other things, what the drug is recommended for, how it is to be administered, and in what quantities it is to be administered." 42 Fed. Reg. 39,767, 39,792 (1977). A party seeking exemption under this grandfather clause must demonstrate that the conditions of use recommended for the new drug used or sold on October 9, 1962 are the same as those currently employed. See Tyler Pharm. Dist., Inc. v. Department of HEW, 408 F.2d 95, 99 (7th Cir. 1969); United States v. Allan Drug Corp., 357 F.2d 713, 719 (10th Cir. 1966).

72 Drug Amendments of 1962, Pub. L. No. 87-781, $\$ 107(c)(4), 76$ Stat. 780 (1962), reprinted in 21 U.S.C. $\$ 321$, note (1976).

73 United States v. An Article of Drug "Bentex Ulcerine," 469 F.2d 875, 878 (5th Cir. 1972), cert. denied, 412 U.S. 938 (1973); United States v. Articles of Drug Labeled Colchicine, 442 F. Supp. 1236, 1242 (S.D.N.Y. 1978); see 42 Fed. Reg. 39,767, 39,787 (1977).

74 Durovic v. Richardson, 479 F.2d 242, 250 n.6 (7th Cir.), cert. denied, 414 U.S. 944 (1973); United States v. An Article of Drug "Bentex Ulcerine," 469 F.2d 875, 878 (5th Cir. 1972), cert. denied, 412 U.S. 938 (1973); United States v. Articles of Drug Labeled Colchicine, 442 F. Supp. 1236, 1242 (S.D.N.Y. 1978); United States v. 1,048,000 Capsules, More or Less, "Afrodex," 347 F. Supp. 768, 770 (S.D. Tex. 1972), aff'd, 494 F.2d 1158 (5th Cir. 1974). 
format and must include evidence of past and present labelings. ${ }^{75}$ Failure to comply with this framework constitutes a complete waiver of any contentions for an exemption. ${ }^{76}$

\section{B. The Regulations Applied}

Laetrile supporters and FDA officials have debated the drug's status under the Act for almost a decade. ${ }^{77}$ The government maintains that the Act applies to laetrile and thus expressly prohibits its distribution in interstate commerce. In contrast, laetrile proponents argue that sufficient evidence exists to prove that laetrile either falls outside the new drug definition of the Act or is exempted by its grandfather clauses. Even though the FDA formalized its views on the drug's legal status in a rulemaking proceeding in $1977,{ }^{78}$ the Rutherford V court's exemption of laetrile from federal regulation under the 1962 grandfather clause demonstrates the continuing controversy over the drug's statutory status. ${ }^{79}$

7521 C.F.R. $\$ 314.200(\mathrm{e})(2)$ (1977).

$7^{\circ} I d$.

77 This disagreement did not crystallize until recently. For years, the FDA informally indicated that laetrile was a "new drug" under the Act, but declined to make a clear determination of the drug's status or develop an administrative record. See Rutherford v. United States, 438 F. Supp. 1287, 1290 n.5 (W.D. Okla. 1977) (Rutherford V), aff'd as modified, No. 77-2049 (10th Cir. July 10, 1978), petition for cert. filed, 47 U.S.L.W. 3278 (U.S. Oct. 10, 1978) (No. 78-605); Rutherford v. United States, 399 F. Supp. 1208, 1212-13 (W.D. Okla. 1975) (Rutherford I), aff'd, remanded on other grounds, 542 F.2d 1137 (10th Cir. 1976) (Rutherford II), modified on remand, 424 F. Supp. 105 (W.D. Okla.) (Rutherford III), modified, 429 F. Supp. 506 (W.D. Okla. 1977) (Rutherford IV). This inaction on the part of the FDA effectively thwarted efforts to attack the regulations, because the FDA has the initial authority to decide the status of a drug. See notes 50-51 supra. If laetrile proponents filed a new drug application, they would have had to admit that the drug was covered by the statute, and thus was not grandfathered. If they did not file an application, the FDA would continue to prohibit the drug without compiling an official record sufficient for judicial review. Rutherford II and Rutherford III alleviated this problem by declaring that the FDA had, in fact, found laetrile to be a new drug, and ordered the agency to produce a supporting administrative record. Rutherford II, 542 F.2d at 1143; Rutherford III, 424 F. Supp. at 107.

7842 Fed. Reg. 39,767 (1977). This proceeding was held in response to the order of Rutherford v. United States, 424 F. Supp. 105 (W.D. Okla.) (Rutherford III), modified, 429 F. Supp. 506 (W.D. Okla. 1977), see note 77 supra, and was announced in 42 Fed. Reg. 10,066 (1977). The hearing took place in Kansas City, Mo., on May 2-3, 1977, and included the testimony of 47 witnesses representing several different viewpoints, including those of laetrile proponents, laetrile opponents, consumers, patients, physicians, researchers, therapists, and government officials. 42 Fed. Reg. 39,767-68 (1977). As a result of this hearing, plus several thousand pages of written submissions, the Commissioner formally confirmed the laetrile ban. Id.

70438 F. Supp. 1287, 1301 (W.D. Okla. 1977), aff'd as modified, No. 77-2049 (10th Cir. July 10, 1978), petition for cert. filed, 47 U.S.L.W. 3278 (U.S. Oct. 10 , 1978) (No. 78-605). The court held that the portions of the administrative record dealing with the 1962 grandfather clause were unsupported, and vacated the Com- 


\section{New Drug Status}

The characterization of laetrile as a new drug first requires evidence that its manufacturers and purchasers intend to use it as a drug. ${ }^{80}$ Courts have often found the requisite intent, ${ }^{81}$ because laetrile is widely publicized as a treatment for cancer and is extensively used for this purpose. Thus, efforts to portray laetrile as a vitamin or a food in order to escape regulation are unlikely to succeed. ${ }^{82}$ There is much less of a consensus within the medical and scientific communities regarding laetrile's safety and effectiveness. For this reason, the following analysis of laetrile will consider all available research on its physical properties as well as prior judicial assessments of the drug.

\section{a. Safety of Laetrile}

The judicial assessments of laetrile's safety involve two distinct questions: first, whether laetrile is actually safe, and second, whether it is generally recognized as safe by qualified experts.

The actual safety of laetrile is a matter of concern to courts for two reasons: ( 1 ) If laetrile is unsafe, it may be subject to seizure and prohibition as an adulterated or misbranded drug, regardless of its status under the grandfather clauses; ${ }^{s 3}$ and (2) If laetrile is actually unsafe, this evidence is useful to show that the substance is generally recognized as unsafe and thus is foreclosed from marketing unless it satisfies the requirements of the new drug application process.

The dispute over the safety of laetrile centers on the allegation that laetrile contains hydrogen cyanide, a highly toxic substance that can be released within the body under certain circumstances.

mission's decision. Laetrile was exempted from the new drug requirements under the 1962 grandfather clause because the court found it to be generally recognized as safe in 1962. See text accompanying notes 120-49 infra.

80 See note 47 supra.

81 See, e.g., Gadler v. United States, 425 F. Supp. 244, 247 (D. Minn. 1977); Hanson v. United States, 417 F. Supp. 30, 35 (D. Minn.), aff'd, 540 F.2d 947 (8th Cir. 1976); United States v. General Research Laboratories, 397 F. Supp. 197, 200 (C.D. Cal. 1975).

82 See, e.g., Rutherford v. United States, 542 F.2d 1137, 1140 (10th Cir. 1976) (Rutherford II), modified on remand, 424 F. Supp. 105 (W.D. Okla.), modified, 429 F. Supp. 506 (W.D. Okla. 1977); Hanson v. United States, 417 F. Supp. 30, 35 (D. Minn.), aff'd, 540 F.2d 947 (8th Cir. 1976). Cf. Millet, Pit and Seed Co., Inc. v. United States, 436 F. Supp. 84, 91 (E.D. Tenn. 1977) (apricot kernels characterized as food supplement, rather than drug, because seller made no representations about them; court emphasized that it was not approving apricot kernels as a disease treatment).

83 Rutherford v. United States, 542 F.2d 1137, 1142 n.4 (10th Cir. 1976) (Rutherford II), modified on remand, 424 F. Supp. 105 (W.D. Okla.), modified, 429 F. Supp. 506 (W.D. Okla. 1977); 21 U.S.C. $\$ 331$ (a) (1976). For a definition of "misbranded," see 21 U.S.C. $\$ 352(\mathrm{j})(1976)$. 
This charge has been confirmed by numerous research studies that indicate that amygdalin and laetrile have caused toxic effects in experimental use. ${ }^{84}$ In addition, the clinical experiences of some physicians, as well as data collected by researchers, provide evidence of poisoning and other severe reactions to laetrile, including neurological disease, fever, hemorrhages, and low blood pressure. ${ }^{85}$ One California researcher documented thirty-seven cases of poisoning and seventeen deaths from the use of laetrile or related fruit kernels. $^{86}$ Although some claim that only ingested laetrile is dangerous, there is no test data to support this distinction. ${ }^{87}$ Thus, the available scientific data indicate that laetrile is not actually safe for human use.

Judicial opinions on the actual safety of laetrile are inconclusive. On the basis of evidence presented to them, several federal courts found laetrile to be toxic, ${ }^{88}$ and granted injunctions preventing its shipment. ${ }^{89}$ On the basis of other evidence, other federal

${ }^{84}$ See Sadoff, Fuchs \& Hollander, Rapid Death Associated With Laetrile Ingestion, $239 \mathrm{~J}$. AMA 1532 (1978) (California specialists report that liquid laetrile may induce cyanide poisoning); Schmidt, Laetrile Toxicity Studies in Dogs, 239 J. AMA 943 (1978) (California researchers report that laetrile is highly toxic in dogs when taken in combination with some common table foods); Smith, Butler, Cohan \& Schein, Laetrile Toxicity: A Report of Two Patients, 62 Cancer Trent. Rep. 169 (1978) [hereinafter cited as Laetrile Toxicity]; CANCER News, Fall 1973-Winter 1974 , at 16 (reporting unsettling evidence of toxicity found by expert oncologists in 1971). But see N.Y. Times, July 12, 1977, at 13, col. I (reporting that National Cancer Institute's tests revealed no toxicity).

85 See Janssen, supra note 2 , at 4 (reporting cyanide poisoning death of tenmonth-old child who ingested father's laetrile); Lewis, supra note 3 , at 58-59 (reporting incidents of toxicity in California, France, Turkey, Israel, and Germany, and among American Indians); Townsend \& Boni, Cyanide Poisoning From Ingestion of Apricot Kernels, 24 Morbm Montal 427 (1975); The Case of the Crushed Kernels, 39 Consumer REPORTs 514 (1974); Laetrile: The Making of a Myth, FDA Consunen, December 1976-January 1977, at 8 [hereinafter cited as Laetrile Myth]; Top Health Officials Cite Laetrile Dangers, FDA Consumer, September 1977, at 4 [hereinafter cited as Laetrile Dangers].

80 Laetrile Dangers, supra note 85 , at 3.

87 See, e.g., 42 Fed. Reg. 39,767, 39,786 (1977) (report of the Ad Hoc Committee for Oncology consultants to the FDA).

88 United States v. Spectro Foods Corp., Civ. No. 76-101 (D.N.J.), aff'd in part, rev'd in part, 544 F.2d 1175 (3d Cir. 1976) (adulterated and misbranded); United States v. General Research Laboratories, 397 F. Supp. 197, 198-99 (C.D. Cal. 1975) (toxic). See Seized Laetrile Valued at $\$ 300,000$, FDA Consumer, September 1977, at 28 (reports Wisconsin court finding that laetrile is unsafe). Even laetrile supporters recognize certain health risks in taking the drug, as evidenced by its labeling. See 42 Fed. Reg. 39,767, 39,786, 39,789 (1977).

89 In United States v. General Research Laboratories, 397 F. Supp. 197 (C.D. Cal. 1975), the district court granted a permanent injunction. In United States v. Spectro Foods Corp., 544 F.2d 1175 (3d Cir. 1976), the Third Circuit upheld the parts of a preliminary injunction that prohibited the interstate shipment of compounds containing laetrile. 
courts found ${ }^{90}$ or assumed ${ }^{91}$ laetrile to be safe. These cases are of limited utility to a determination of laetrile's present safety in actual use. First, it is notable that these rulings were made prior to the publication of the latest scientific studies. Indeed, one court examined only one objective study of laetrile's toxicity before deciding the issue.92 Second, the opinions failed to articulate the standard or techniques used to determine the safety of the drug. In view of these problems and the mounting scientific evidence of laetrile's toxicity, the judgment of the scientific community merits judicial concurrence.

The issue of general recognition has evoked a more uniform reaction from the judiciary. In United States $v$. General Research Laboratories ${ }^{93}$ the court found that "[a]mygdalin [laetrile] is not generally recognized by experts qualified by scientific training and experience to evaluate its safety, as having been shown through scientific procedures . . . to be safe under the conditions of its use in the articles B 17 and Aprikern [laetrile-containing compounds]." 94 Similarly, the Rutherford V court held that laetrile is not generally recognized as safe, stating that "the evidence of the record does not render the Commissioner's conclusion that laetrile is not 'generally recognized as safe and effective' arbitrary and capricious." 95

The conclusion reached by these courts was mandated by several facts. First, the Supreme Court's requirement that findings of general recognition be based on "substantial evidence," including published scientific data, ${ }^{96}$ was not satisfied. Second, the substance and weight of the scientific reports on laetrile's safety suggest that there is a substantial difference of opinion ${ }^{97}$ regarding laetrile's

90 Rutherford v. United States, 438 F. Supp. 1287, 1297 (W.D. Okla. 1977), aff'd as modified, No. 77-2049 (10th Cir. July 10, 1978), petition for cert. filed, 47 U.S.L.W. 3278 (U.S. Oct. 10, 1978) (No. 78-605). The Rutherford I court specifically found that laetrile is nontoxic and an effective cancer remedy. Rutherford $v$. United States, 399 F. Supp. 1208, 1212 (W.D. Okla. 1975), affd, 542 F.2d 1137 (10th Cir. 1976) (the government introduced no evidence in regard to these issues).

91 Rizzo v. United States, 432 F. Supp. 356, 359 n.4 (E.D.N.Y. 1977) (court granted preliminary injunction to enable plaintiff to import laetrile for his own use).

02 Rutherford v. United States, 438 F. Supp. 1287, 1297 n.23 (W.D. Okla. 1977), aff'd as modified, No. 77-2049 (10th Cir. July 10, 1978), petition for cert. filed, 47 U.S.L.W. 3278 (U.S. Oct. 10, 1978) (No. 78-605).

93397 F. Supp. 197 (C.D. Cal. 1975).

84 Id. 199.

95 Rutherford v. United States, 438 F. Supp. 1287, 1293 (W.D. Okla. 1977), aff'd as modified, No. 77-2049 (10th Cir. July 10, 1978), petition for cert. filed, 47 U.S.L.W. 3278 (U.S. Oct. 10, 1978) (No. 78-605).

96 See Weinberger v. Hynson, Westcott \& Dunning, Inc., 412 U.S. 609, 632 (1973); 42 Fed. Reg. 39,767, 39,775-76 (1977).

87 See notes $55-57$ supra. 
safety, a fact that negates the possibility of a generally-recognized consensus about the drug. Third, conflicting testimony at the FDA's rule-making proceeding ${ }^{98}$ and before the two courts demonstrates that there is no expert consensus on the issue of laetrile's safety.

\section{b. Effectiveness of Laetrile}

A pivotal issue in resolving the laetrile controversy is the drug's effectiveness; the resolution of this issue has several implications. First, if laetrile were generally recognized as safe, it would also have to be generally recognized as effective in order to avoid the premarketing requirements of the new drug application process. Second, if laetrile is actually effective in treating cancer, restrictions on its use are much more difficult to justify: an effective cancer treatment, even if unsafe, would be a medical boon. Under such circumstances, a determination of laetrile's marketability should balance the degree of actual effectiveness against the magnitude of the danger from use of the drug. Third, a finding of actual effectiveness would adversely affect a court's decision regarding the constitutionality of the laetrile ban, since the government has a diminished interest in keeping effective cancer remedies off the market.

In evaluating the available objective evidence of laetrile's actual effectiveness, it is important to note that the drug has been subjected to extensive testing, often by qualified researchers. ${ }^{99}$ Most laetrile researchers, however, have investigated the drug's effects on animal, rather than human, tumor systems. Although these tests do not fulfill statutory requirements, it is standard research procedure to screen out potential active chemotherapeutic agents through animal testing. If the animal tumors show a beneficial response to a substance, this provides a basis for clinical testing on humans. ${ }^{100}$

The record indicates that laetrile has been investigated more than a dozen times, and the conclusion of each study has been that

98 Fourteen cancer experts and researchers gave testimony or affidavits to the FDA indicating that laetrile has never been generally recognized as safe, nor has it been proven to be safe in fact. 42 Fed. Reg. 39,767, 39,786-87 (1977). In contrast, a number of physicians testified before the Oklahoma District Court to the effect that their experiences showed laetrile to be nontoxic in common doses. Rutherford v. United States, 438 F. Supp. 1287, 1297 n.23 (W.D. Okla. 1977).

99 Lewis, supra note 3 , at 56.

100 See 42 Fed. Reg. 39,767, 39,781 (1977); Laetrile Myth, supra note 85, at 7. The "FDA has been on record for years as being prepared to approve human tests of Laetrile if experts in cancer found evidence to justify them." Id. See also note 41 supra. 
laetrile is worthless in preventing, curing, or inhibiting cancerous growths. ${ }^{101}$ For example, the Sloan-Kettering Institute for Cancer Research concluded, after a four-year study, that no evidence exists showing that laetrile is beneficial. ${ }^{102}$ The National Cancer Institute's researchers also found laetrile to be ineffective. ${ }^{103}$

Most clinical reports parallel the unfavorable animal tumor results. Physicians from several nations have reported, on the bases of case studies and clinical investigations, that laetrile fails to control human cancer. ${ }^{104}$ The evidence to the con-

101 See 42 Fed. Reg. 39,767, 39,780 (1977) (reporting study of the Institute von Ardenne in 1973); Culliton, Sloan-Kettering: The Trials of an Apricat Pit-1973, 182 SCIENCE 1000 (1973) (Sloan-Kettering Institute); Hill, Shine, Hill \& Miller, Failure of Amygdalin to Arrest B16 Melanoma and BW5147 AKR Leukemia, 36 Cancer Res. 2102 (1976) (Washington University School of Medicine); Laster \& Schabel, Experimental Studies of the Antitumor Activity of Amygdalin MF (NSC15780) Alone and in Combination With B-Glucosidase (NSC-128056), 59 CANCER Chemother. Rxp. 951 (1975) (Southern Research Institute); Levi, French, Beckis \& Henderson, Laetrile: A Study of its Physico-Chemical Properties, 92 CAN. MED. Assoc. J. 1057 (1965); Lewis, supra note 3, at 56 (reporting studies of the National Cancer Institute in 1957, 1960,1969, 1973, 1975, of the Scind Research and Development Company in 1968, and of the Cancer Commission of the California Medical Association in 1953); Wodinsky \& Swiniarski, Antitumor Activity of Amygdalin MF (NSC-15780) as a Single Agent and With B-Glucosidase (NSC-128050) on a Spectrum of Transplantable Rodent Tumors, 59 CANCER CHEMother. Rep. 939 (1975) (study conducted by the Arthur D. Little Company); N.Y. Times, July 17, 1977, $\$$, at 10, col. 1 (reporting study of the Battelle Medical Institute of Columbus, Ohio).

But see 42 Fed. Reg. 39,767, 39,780 (1977) (unpublished study from Pasteur Institute reported in 1971). It is notable that all of the other drugs known to have a positive effect in certain cancer cases have demonstrated significant activity in animal tumor systems. Id. 39,781; Testimony Invited on the Status of Laetrile, FDA Consumer, March 1977, at 26.

The FDA Commissioner concluded, upon examination of available studies, that there is no evidence to warrant the belief that laetrile has anticancer activity in laboratory animals, 42 Fed. Reg. 39,767, 39,781 (1977).

102 Janssen, supra note 2, at 5; 42 Fed. Reg. 39,767, 39,780 (1977). A spokesman for the Institute concluded that there is no scientific evidence from the animal investigations to warrant conducting human tests. He also noted that the positive preliminary results obtained by one researcher in 1973 have never been duplicated. 103 N.Y. Times, July 12, 1977, at 13, col. 1.

$104 \mathrm{See} 42 \mathrm{Fed}$. Reg. 39,767, 39,778-79 (reporting study of case histories by 1963 Cancer Advisory Council of California Department of Health); California Medical Ass'n, Report: The Treatment of Cancer with Laetriles, 78 CAL. MED. 320 (1953); Lewis, supra note 3, at 56 (1970 study of laetrile in clinical trials at Mexican cancer center); Marrone, Chemotherapy of Inoperable Cancer, 20 Exp. MED. SuRg. 299 (1962) (case reports of American researcher); Navarro, Laetrile-The Ideal AntiCancer Drug?, 9 Sr. Thomas J. MEd. 468 (1954) (investigational siudy by Filipino specialist); CaNcen News, Fall 1973-Winter 1974, at 16 (1973 study of 190 case histories by the California Public Health Department).

The National Cancer Institute recently initiated a study of cancer patients who have used laetrile, asking physicians to submit names of consenting patients who may have shown a response to the drug. In response, the Institute received information from 93 patients, but only 22 of the case histories were sufficiently documented and controlled to warrant review. Study of these cases revealed that six patients had shown improvement after laetrile treatment, but the drug's adverse or negligible effects on the other 16 patients rendered the study inconclusive. As a result of this 
trary ${ }^{105}$ is generally undocumented in form and unscientific in methodology. ${ }^{106}$

Notwithstanding the existence of clear evidence that the physiological effects of laetrile are minimal, proponents of laetrile claim that the drug is effective because it is psychologically beneficial, especially for pain reduction. ${ }^{107}$ Even assuming that this is true, laetrile is not "effective" within the intent of the statute. Congress did not choose to legalize drugs that have unpredictable or negligible effects. The use of the word "effective" by Congress implies that a drug must have a proven capacity for producing the desired result, not merely the potential to do so. ${ }^{108}$ Thus, evidence indicating that laetrile may cause a psychological uplift in some patients only demonstrates that the drug is potentially helpful or efficacious for the treatment of cancer, but not effective for this purpose.

Courts have not held that laetrile is generally recognized as an effective cancer treatment, ${ }^{109}$ basing their reluctance upon the broad consensus against the drug within the scientific and medical communities. The nation's leading medical and cancer-fighting institutions maintain that laetrile is not a helpful cancer cure or treat-

minimal evidence of anti-tumor effects and the widespread use of laetrile pursuant to the Rutherford VI injunction, however, the NCI has announced plans to resolve conclusively the issue of effectiveness, through clinical testing on several hundred terminal patients. The NCI intends to review the records of these patients and initiate human tests if there is any evidence of antiumor effects. Laetrile Evaluation Underway at NCI, 239 J. AMA 19 (1978); Philadelphia Inquirer, September 28, $1978, \S A$, at 3 , col. 3 .

100 See 42 Fed. Reg. 39,767, 39,777-78 (1977) (testimony of three physicians who administer laetrile, about their own case studies); Lewis, supra note 3 , at 58 (1970 study of 35 case histories by German researcher); N.Y. Times, December 21, 1975, at 40, col. I (physician's survey of 500 patients).

10642 Fed. Reg. 39,767, 39,777 (1977).

107 See Rutherford v. United States, 438 F. Supp. 1287, 1294 (W.D. Okla. I977), aff'd as modified, No. 77-2049 (10th Cir. July 10, 1978), petition for cert. filed, 47 U.S.L.W. 3278 (U.S. Oct. 10, 1978) (No. 78-605); Rizzo v. United States, 432 F. Supp. 356, 359 (E.D.N.Y. 1977); N.Y. Times, December 21, 1975, at 40, col. 1. But see 42 Fed. Reg. 39,767, 39,777 (1977).

108 See The American Heritage Drctionary 416 (1969). The dictionary provides a useful explanation of the distinction between "effective," "efficacious," and "effectual." "Effective" and "effectual" imply a proven capacity; "efficacious" implies a potential one. Laetrile may be an efficacious cancer drug, but it is not an effective one.

109 See Rutherford v. United States, 438 F. Supp. 1287, 1293 (W.D. Okla. 1977) (court upheld FDA decision that laetrile is not generally recognized as safe and effective), aff'd as modified, No. 77-2049 (10th Cir. July 10, 1978); petition for cert. filed, 47 U.S.L.W. 3278 (U.S. Oct. 10, 1978) (No. 78-605). See also Gadler v. United States, 425 F. Supp. 244, 247 (D. Minn. 1977); Hanson v. United States, 417 F. Supp. 30, 35-36 (D. Minn. 1976). In these cases seeking preliminary injunctions to obtain laetrile, courts found that plaintiffs could not show substantial probability of success. Cf. 42 Fed. Reg. 39,767, 39,786 (1977) (rulemaking procedure of FDA holds that laetrile is not generally recognized as effective). 
ment. ${ }^{110}$ Similarly, a significant number of medical journals and periodicals oppose the use of laetrile due to its proven ineffectiveness. ${ }^{111}$ This lack of general recognition was further demonstrated by the expert testimony at the recent FDA proceeding. Over thirty highly-qualified cancer researchers and physicians testified that the clear consensus of opinion within the field is that laetrile is useless. ${ }^{112}$ Even taking into account the views of those physicians and experts who favor the use of laetrile, ${ }^{113}$ it is clear that there is insufficient support for a finding of generally recognized effectiveness. 114

The preceding discussion yields two important conclusions. First, the existing scientific evidence indicates that laetrile is not actually safe and effective. As a result, it is unlikely that the drug will be approved for marketing by the new drug application process. Second, the drug is not presently "generally recognized as safe and effective" by qualified experts. Therefore, it cannot be marketed as a cancer drug under the Act unless a grandfather clause exemption is applicable.

\section{Exemption Status}

As previously noted, ${ }^{115}$ the stringent substantive and procedural requirements governing the grandfather clause exemptions effectively deter their invocation in most cases. Nevertheless, laetrile proponents have, on several occasions, tried to circumvent the FDA's prohibition by appealing to the courts for an exemption from the Act.

Attempts to exempt laetrile under the 1938 grandfather clause have been rebuffed by the courts because of insufficient evidence to

110 Organizations that question the efficacy of laetrile include the American Cancer Society, the National Cancer Institute, the American Medical Association, the Committee on Neoplastic Diseases of the American Academy of Pediatrics, the Food and Drug Administration, and the Canadian Food and Drug Directorate. See 42 Fed. Reg. 39,767, 39,781 (1977); Laetrile Myth, supra note 85, at 6.

111 See, e.g., DiPalma, Laetrile: When is a Drug Not a Drug?, 15 Aм. FaM. Prys. 186 (1977); Greenburg, The Vitamin Feud in Cancer Quackery, 122 W.J. MED. 345 (1975); Jukes, Laetrile for Cancer, 236 J. AMA 1284 (1976); Morris, Potential for Tragedy in Public Overplay of Cancer "Cures," 113 CaN. MEd. A.J. 465 (1975); 170 ChEST 407 (1976); 169 Chest 331 (1976).

11242 Fed. Reg. 39,767, 39,781-85 (1977).

113 A total of 11 physicians with varying qualifications testified or submitted affidavits to the Food and Drug Administration in support of laetrile's claimed effectiveness. Id. 39,785-86.

114 Rutherford v. United States, 438 F. Supp. 1287 (W.D. Okla. 1977), aff'd as modified, No. 77-2049 (10th Cir. July 10, 1978), petition for cert. filed, 47 U.S.L.W. 3278 (U.S. Oct. 10, 1978) (No. 78-605); see text accompanying notes $55-57$ supra.

115 See text accompanying notes 73-76 supra. 
make a showing of compliance with the terms of the clause. ${ }^{116}$ Several factors justified this conclusion. First, no evidence indicates that the past and present compositions of laetrile are identical. ${ }^{117}$ Second, the manner in which laetrile was labeled prior to 1938 is unknown. ${ }^{118}$ Third, no evidence demonstrates that laetrile's conditions of use (dosage, manner of administration, etc.) have remained consistent over the past four decades. ${ }^{119}$

Efforts to claim a 1962 grandfather clause exemption for laetrile have been more successful: the district court in Rutherford V struck down in its entirety the FDA's prohibition of laetrile on the ground that the drug was exempt from federal regulation under the 1962 provision. ${ }^{120}$ In reaching its decision the court found that laetrile was generally recognized as safe by qualified experts in 1962 . Because the case was certified as a class action, ${ }^{121}$ the court's finding may have a significant impact on the federal regulation of laetrile, and therefore should be scrutinized closely.

The court's finding that laetrile was generally recognized as safe in 1962 is flawed in two respects. In weighing the conflicting testimony of laetrile's proponents and detractors, the court emphasized the former's practical experience with the drug. ${ }^{122}$ This reliance on practical experience, while embodying some superficial appeal, has the effect of selecting a biased sample of the expert opinion. Those researchers who believe in laetrile are likely to go on using it; those who have determined that the drug is worthless will stop. Thus, in making the determination that laetrile was generally recognized as safe, the court used a sample that was smaller than the FDA's and included a higher percentage of laetrile

110 See Rutherford v. United States, 438 F. Supp. 1287, 1298 (W.D. Okla. 1977), aff'd as modified, No. 77-2049 (10th Cir. July 10, 1978), petition for cert. filed, 47 U.S.L.W. 3278 (U.S. Oct. 10, 1978) (No. 78-605); Gadler v. United States, 425 F. Supp. 244, 247-48 (D. Minn. 1977); Hanson v. United States, 417 F. Supp. 30, 36 (D. Minn.), aff'd, 540 F.2d 947 (8th Cir. 1976).

11742 Fed. Reg. 39,767, 39,789 (1977).

118 See id. 39,790; Gadler v. United States, 425 F. Supp. 244, 248 (D. Minn. 1977).

118 Rutherford v. United States, 438 F. Supp. 1287, 1298 (W.D. Okla. 1977), aff'd as modified, No. 77-2049 (10th Cir. July 10, 1978), petition for cert. filed, 47 U.S.L.W. 3278 (U.S. Oct. 10, 1978) (No. 78-605); Gadler v. United States, 425 F. Supp. 244, 248 (D. Minn. 1977).

120438 F. Supp. 1287, 1295 (W.D. Okla. 1977), aff'd as modified, No. 77-2049 (10th Cir. July 10, 1978), petition for cert. filed, 47 U.S.L.W. 3278 (U.S. Oct. 10, 1978) (No. 78-605).

121 See note 11 supra.

122438 F. Supp. 1287, 1293, 1295 n.18 (W.D. Okla. 1977), aff'd as modified, No. 77-2049 (10th Cir. July 10, 1978), petition for cert. filed, 47 U.S.L.W. 3278 (U.S. Oct. 10, 1978) (No. 78-605). 
supporters. In effect, the court merely concluded that among laetrile proponents, the drug was generally recognized as safe in 1962.

A second problem with the court's finding is that it fails to deem significant the fact that there is no pre-1962 scientific literature that documents laetrile's safety. In 1973, the Supreme Court construed the phrase "generally recognized" as it appears in 21 U.S.C. $\$ 321(\mathrm{p})$ to require that any expert consensus be "based on controlled clinical experimentation and backed by substantial support in scientific literature." ${ }^{123}$ To the extent that the same phrase in the pre-1962 version of the section has the same meaning, the finding that laetrile was "generally recognized" by qualified experts as safe in 1962 must also have "substantial support in the scientific literature." 124 The Rutherford V court's references to one laboratory study ${ }^{125}$ and to two "authoritative" ${ }^{126}$ publications that were at least twelve years old in $1962{ }^{127}$ hardly qualify as substantial support.

\section{Applicability of the Statute to the Terminally Ill}

The Tenth Circuit's decision in Rutherford VI alters the focus of the statutory analysis of laetrile. Rather than deciding the questions of general recognition for safety and effectiveness, or the effect of the grandfather clauses, the court held that the Act does not apply to terminally-ill cancer patients. ${ }^{128}$ In arriving at this decision the court made several unwarranted assumptions.

Before examining the validity of these assumptions, it is useful to consider the effects of the decision. First, it removes a large class of persons from the protection of the Food, Drug, and Cosmetic Act. Second, although the statute was enacted to protect the drugconsuming public, the Rutherford VI court reasoned that terminally-ill patients have no need of this statutory protection because

123 Weinberger v. Bentex Pharm., Inc., 412 U.S. 645, 652 (1973); see Weinberger v. Hynson, Westcott \& Dunning, Inc., 412 U.S. 609,632 (1973).

124 Weinberger v. Bentex Pharm., Inc., 412 U.S. 645, 652 (1973).

125 Rutherford v. United States, 438 F. Supp. 1287, 1297 n.23 (W.D. Okla. 1977), aff'd as modified, No. 77-2049 (10th Cir. July 10, 1978), petition for cert. filed, 47 U.S.L.W. 3278 (U.S. Oct. 10, 1978) (No. 78-605).

126 Id. 1298 n.24.

$127 \mathrm{Id}$.

128 See Rutherford v. United States, No. 77-2049, slip op. at 5 (10th Cir. July 10, 1978) (Rutherford VI), petition for cert. fled, 47 U.S.L.W. - (U.S. Oct. 10, 1978) (No. 78-605). See also Rutherford v. United States, 438 F. Supp. 1287 (W.D. Okla. 1977) (Rutherford V), aff'd as modified, No. 77-2049 (10th Cir.), petition for cert. fled, 47 U.S.L.W. 3278 (U.S. Oct. 10, 1978) (No. 78-605); Comment, Freedom of Choice in Medical Treatment: Reconsidering the Efficacy Requirement of the FDCA, 9 LOY. CFr. L.J. 205 (1977) [hereinafter cited as Freedom of Choice]. 
their death is inevitable. This reasoning could open the market to a flood of unsafe and useless nostrums directed to the terminally ill. Before acceding to such a dramatic reduction in patient protection, the underlying bases of the court's reasoning should be scrutinized.

The court assumed that it is easy to define a class consisting of terminally-ill patients. The court stated that "[i]t would not seem difficult to define the group to which this determination of a legal issue applies. A licensed medical practitioner can express an opinion as to whether, under the present state of the art, a particular person is terminally ill with cancer, and to so certify." 120 Given the impact in diminished drug protection of being certified as terminally ill under the court's reasoning, allowing this decision to be made independently by any one doctor is not justifiable. The court erroneously assumed that terminal patients are an easily-definable class. In fact, in many cases, there is no reliable distinction between terminal and non-terminal patients. ${ }^{130}$ In light of the difficulty of applying its reasoning, the court is too cavalier in removing the protections of the Act.

The Tenth Circuit also incorrectly assumed "that no applicable or reasonable measure exists" to determine a drug's safety and effectiveness for a terminally-ill patient. ${ }^{131}$ In regard to safety, this argument is patently wrong. A drug that accelerates death is "unsafe," even for the terminally ill. Proper controls, such as those normally instituted by the FDA, keep these dangerous drugs off the market. Similarly, it is erroneous to assume that all treatments are equally effective for terminal patients. Some orthodox treatments are "effective" in that they have a proven capacity to prolong the patient's life; ${ }^{132}$ laetrile's effectiveness is unproven for any class of cancer patient. ${ }^{133}$ There is, therefore, a reasonable standard to determine a drug's safety and effectiveness for the terminally ill: a drug that shortens a patient's life expectancy is unsafe; a drug that fails to lengthen life expectancy, especially when other remedies could do so, is ineffective.

129 No. 77-2049, slip op. at 5 (10th Cir. July 10, 1978), petition for cert. flled, 47 U.S.L.W. 3278 (U.S. Oct. 10, 1978) (No. 78-605).

130 This definitional problem is inherent in the nature of the disease. Cancer varies greatly in its behavior, rate of growth, pattern of spread, symptoms, effects on organs, and chances of recovery for the patient. Physicians are therefore unable to predict the outcome of cancer at any given stage of development. 42 Fed. Reg. 39,767, 39,779 (1977); Laetrile Myth, supra note 85 , at 8.

131 No. 77-2049, slip op. at 5 (10th Cir. July 10, 1978), petition for cert. fled, 47 U.S.L.W. 3278 (U.S. Oct. 10, 1978) (No. 78-605).

132 Laetrile Myth, supra note 85, at 5-6.

133 See text accompanying notes 99-106 supra. 
Even if the erroneous assumptions made by the Rutherford VI court were correct, the decision would still not be justifiable. The statute does not mandate a comparison of the relative effectiveness of possible remedies. ${ }^{134}$ Rather, it sets up an objective, scientific standard that clearly is intended to apply to all drugs facing regulation.

Thus, the action taken by the Tenth Circuit exceeds its adjudicatory function. The court did not interpret the Food, Drug, and Cosmetic Act; it judicially amended the Act to create an exception that the drafters did not intend to include. The court should have deferred to Congress to amend the Act and provide the exception. Indeed, there is legislation pending in Congress that would permit the FDA to consider the relative safety and effectiveness of drugs intended for terminal patients. ${ }^{135}$ For the reasons stated above, a judicially-created exception to the Act for terminal patients must be based on constitutional rather than statutory grounds.

\section{Constitutional Considerations}

The legal status of laetrile under the Federal Food, Drug, and Cosmetic Act ${ }^{136}$ (the "Act") is not dispositive of all the issues in question. An underlying issue that must be addressed in order to resolve conclusively the laetrile controversy is the extent of the government's constitutional authority to regulate an individual's privately-made decision to use laetrile as a cancer treatment.

There are two philosophical bases supporting the state's power to control personal health care. One, grounded in the social contract theory, sanctions governmental interference with individual liberty when a person's actions threaten the welfare of the collective community. ${ }^{137}$ The other maintains that self-destructive conduct,

1341962 Senate Report, supra note 35, at 8, [1962] U.S. Code Cong. \& AD. NEws at 2892.

135 S. 2755, 95th Cong., 2d Sess. 42-43, 124 Cong. Rec. 3871 (1978); H.R. 11611, 95th Cong., 2d Sess. 42-43, 124 Cong. Rec. 2184 (1978). The proposed legislation would eliminate the new drug application licensing concept and replace it with a three-phase approval process. First, in the innovational or discovery stage, studies would be conducted on animals and some humans. Second, the drug sponsor would continue tests designed to document the drug's safety and effectiveness and develop information on conditions of use. Third, the approval process would conclude with the manufacturer's application for a drug monograph and a marketing license. The monograph would identify the drug's ingredients, prescribe standards for use and distribution, and describe the products covered. See [1978] Foon Drug Cos. L. ReP. (CCH) $\Uparrow 42,217$.

13621 U.S.C. $\$ \$ 301-392$ (1976).

137 People v. Privitera, 74 Cal. App. 3d 936, 959 n.9, 141 Cal. Rptr. 764, 777 n.9 (1977), quoting J.S. MILL, ON LIBERTy 17-18 (G. Routledge ed. 1905). Mill 
such as suicide, narcotics abuse, or even riding a motorcycle unhelmeted, can be regulated or prohibited..$^{138}$ These principles pose two fundamental questions that are crucial to a constitutional analysis of laetrile regulation: (1) Does an individual's use of laetrile threaten the collective community? and (2) Is an individual's use of laetrile tantamount to self-destructive behavior? If the state can prove that either question should be answered in the affirmative, it is probable that laetrile use can be constitutionally prohibited.

A proper constitutional analysis of this problem involves a three-step approach. First, the nature of the individual interests affected by the government's regulation of personal health care is examined in light of recent cases that found a constitutional right to use laetrile. Second, several of the government's interests in prohibiting the commercial and personal use of laetrile are balanced against these personal interests. Third, the applicability of this balance is considered for all classes of patients and in light of possible alternative means to achieve these governmental goals.

\section{A. Personal Health Care Interests}

Proponents of laetrile argue that the regulations of the Food, Drug, and Cosmetic Act, and similar state laws, ${ }^{139}$ deprive them of a constitutional right to obtain and use particular health care treatments. Recent laetrile cases have supported this position by recognizing the constitutional right of cancer patients to obtain and use laetrile, ${ }^{140}$ and also the independent right of physicians to prescribe it without interference. ${ }^{141}$ These cases establish that the right to choose a particular form of health care is fundamental. Thus, any

notes that "[t]he only part of the conduct of any one, for which he is amenable to society, is that which concerns others. In the part which merely concerns himself, his independence is of right, absolute. Over himself, over his own body and mind, the individual is sovereign." Id.

138 See, e.g., Paris Adult Theater I v. Slaton, 413 U.S. 49, 68 n.15 (1973); Robinson v. California, 370 U.S. 660 (I962).

139 The California Cancer Law, CaL. Healtr \& SAFetr Code $\$ 1707.1$ (West 1970), prohibits the sale, purchase, prescription, or administration of unapproved cancer treatments such as laetrile. Patients will therefore face the same difficulties as encountered under the Federal Act in their attempts to obtain and use desired drugs.

140 See Rutherford v. United States, 438 F. Supp. 1287, 1298-1301 (W.D. Okla. 1977), affd as modified, No. 77-2049 (10th Cir. July 10, 1978), petition for cert. filed, 47 U.S.L.W. 3278 (U.S. Oct. 10, 1978) (No. 78-605); People v. Privitera, 74 Cal. App. 3d 936, 947-52, 141 Cal. Rptr. 764, 769-72 (1977); Suenram v. Society of Valley Hospital, 155 N.J. Super. 593, 601-03, 383 A.2d 143, 148 (1977).

141 See People v. Privitera, 74 Cal. App. 3d 936, 952-54, 141 Cal. Rptr. 764, 773-74 (1977). 
restrictions upon this right must be justified by "compelling" state interests, narrowly drawn. ${ }^{142}$

Rutherford, V, People v. Privitera, ${ }^{143}$ and Suenram v. Society of Valley Hospital ${ }^{144}$ grounded this fundamental right within the constitutionally-recognized right of privacy ${ }^{145}$-a right that is the subject of considerable dispute as to its origins ${ }^{146}$ and its breadth. ${ }^{147} \mathrm{Al}$ though the Supreme Court has never specifically extended the right

142 The court in Rutherford v. United States, 438 F. Supp. 1287 (W.D. Okla. 1977) (Rutherford V), aff'd as modified, No. 77-2049 (10th Cir. July 10, 1978), petition for cert. filed, 47 U.S.L.W. 3278 (U.S. Oct. 10, 1978) (No. 78-605), held that "[w]hen certain 'fundamental rights" are invoked, such as the right of privacy involved herein, regulation may be justified only by a 'compelling state interest,' and Iegislative enactments 'must be narrowly drawn to express only the legitimate state interests at stake." 438 F. Supp. at 1300 (citing Roe v. Wade, 410 U.S. 113, 155 (1973)). See People v. Privitera, 74 Cal. App. 3d 936, 947, 141 Cal. Rptr. 764, 769 (1977). For an examination of whether the government has compelling interests to overcome a fundamental privacy right, see notes 189-211 infra \& accompanying text. For an examination of the narrowness of the current regulations, see notes 212-26 infra \& accompanying text.

14374 Cal. App. 3d 936, 141 Cal. Rptr. 764 (1977).

144155 N.J. Super. 593, 383 A.2d 143 (1977).

145 See Rutherford v. United States, 438 F. Supp. 1287, 1299 (W.D. Okla. 1977), aff'd as modified, No. 77-2049 (10th Cir. July 10, 1978), petition for cert. fled, 47 U.S.L.W. - (U.S. Oct. 10, 1978) (No. 78-605); People v. Privitera, 74 Cal. App. 3d 936, 946, 141 Cal. Rptr. 764, 768 (1977); Suenram v. Society of Valley Hospital, 155 N.J. Super. 593, 602-03, 383 A.2d I43, 148 (1977).

146 The right of privacy is never mentioned explicitly in the Constitution. In a number of Supreme Court cases, however, different Justices have found various justifications for its recognition as a constitutional principle. In Griswold v. Connecticut, 381 U.S. 479 (1965), Justice Douglas maintained that the right of privacy is grounded in the "penumbras" that emanate from the more specific guarantees of the Bill of Rights. Id. 434-85. In the same case, Justice Goldberg found the right to stem from the ninth amendment's protection of unenumerated rights, id. 486-87 (Goldberg, J., concurring). In the 1973 abortion decisions, Justice Blackmun, speaking for the Court, found the source of the privacy right to lie in the concept of "ordered liberty" guaranteed by the fourteenth amendment. Roe v. Wade, 410 U.S. 113, 153 (1973); accord, Paul v. Davis, 424 U.S. 693, 713 (1976). Other possible sources of the right of privacy include the first amendment, see Stanley $v$. Georgia, 394 U.S. 557, 564 (1969), and the fourth and fifth amendments, see Terry v. Ohio, 392 U.S. I (1968); Katz v. United States, 389 U.S. 347, 350 (I967).

147 Judges have lamented the fact that the privacy right is undefined and unwieldy. See, e.g., Whalen v. Roe, 429 U.S. 589,599 n.24 (1977); Griswold v. Connecticut, 381 U.S. 479, 530 n.7 (1965) (Stewart, J., dissenting). The privacy right has been described as "the right to be free, except in very limited circumstances, from unwarranted governmental intrusions," Stanley v. Georgia, 394 U.S. 557, 564 (1969), and "the right to be let alone," Olmstead v. United States, 277 U.S. 438, 478 (1928) (Brandeis, J., dissenting).

Commentators have written extensively concerning the right to privacy and its nebulous boundaries. See, e.g., Beaney, The Right to Privacy and American Law, 31 Law \& Contem. Pros. 253 (1966); Ely, The Wages of Crying Wolf: A Comment on Roe v. Wade, 82 Yare L.J. 920, 929 (1973); Henkin, Privacy and Autonomy, 74 Colvis. L. Rev. 1410 (1974); Note, Roe and Paris: Does Privacy Have a Principle?, 26 Stan. L. Rev. 1160 (1974). See also Gerety, Redefining Privacy, 12 Harv. Crv. Rrs.-Crv. Lrb. L. Rev. 233 (1977); Note, Toward a Constitutional Theory of Individuality: The Privacy Opinions of Justice Douglas, 87 Y YcE L.J. 1579 (1978) [hereinafter cited as Privacy Opinions]. 
of privacy to cover personal health care choices, ${ }^{148}$ it has protected privacy interests in many closely-related areas, including marriage, ${ }^{149}$ contraception, ${ }^{150}$ and procreation. ${ }^{151}$ The validity of the recent cases that declare it a fundamental right to choose laetrile must be examined in light of these Supreme Court decisions.

\section{Protected Zones of Privacy}

Arguments in favor of a constitutional right to decide whether to obtain and use laetrile characterize the decision as protected because it is within a constitutional zone of privacy, and thus is immune from all but compelling governmental interference. Rutherford $\mathrm{V}$ relied upon Roe $v$. Wade ${ }^{152}$ to support this view..$^{153}$ Roe established that a woman's decision whether to undergo an abortion is constitutionally protected. Although courts considering laetrile view this case as establishing a zone of privacy around health care decisions, the Supreme Court decided the case on the basis of a zone of privacy around the decision whether or not to bear a child.154 Similarly, the cases that established the right to use contraceptivesGriswold v. Connecticut ${ }^{155}$ and Eisenstadt $v$. Baird ${ }^{150}$-found the birth control decision to be protected by the privacy of the marital relationship ${ }^{157}$ and by the privacy of the decision whether to "bear or beget a child," 158 not by a privacy right to choose a particular form of medical treatment. The identification of the right to choose a specific form of health care, therefore, does not automatically flow from the abortion cases. ${ }^{159}$

148 For an examination of the right to privacy in the health care context, see Comment, Picking Your Poison: The Drug Efficacy Requirement and the Right of Privacy, 25 U.C.L.A. L. REv. 577, 590-607 (1978) [hereinafter cited as Picking Your Poison].

149 Loving v. Virginia, 388 U.S. 1 (1967); Griswold v. Connecticut, 381 U.S. 479 (1965).

150 See Eisenstadt v. Baird, 405 U.S. 438 (1972).

151 See Skinner v. Oklahoma, 316 U.S. 535 (1942).

152410 U.S. 113 (1973).

153438 F. Supp. 1287, 1299 (W.D. Okla. 1977), aff'd as modified, No. 77-2049 (10th Cir. July 10, 1978), petition for cert. filed, 47 U.S.L.W. - (U.S. Oct. 10, 1978) (No. 78-605).

154410 U.S. 113,154 (1973).

155381 U.S. 479 (1965).

156405 U.S. 438 (1972).

157381 U.S. $479,485-86$ (1965).

158405 U.S. 438,453 (1972).

159 One argument against an automatic extension of the privacy right to laetrile users is that the Court has been reluctant formally to extend the right of privacy into new areas of personal decisionmaking. See Doe v. Commonwealth's Attorney, 425 U.S. 901 (1976) (homosexuality); Fitzgerald v. Porter Memorial Hospital, 523 F.2d 716 ( 7 th Cir.), cert. denied, 425 U.S. 916 (1976) (father's interest in observing his wife's delivery of their child). 
Courts that have found a constitutional right to use laetrile also have relied upon the idea that the control of one's body is constitutionally protected. ${ }^{\mathbf{1 B 0}}$ There are several nonconstitutional cases that establish the principle of bodily inviolability. ${ }^{161}$ Privitera, for example, quotes from Schloendorff v. Society of New York Hospital, ${ }^{162}$ a case providing civil remedies for the infringement of bodily integrity, as support for this proposition. Similarly, the federal government has accorded great weight to the interest in bodily integrity. ${ }^{163}$ In addition, a constitutional right to bodily control may be derived from the fourth amendment's protection of "per-

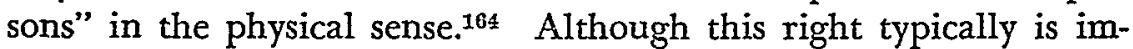
plicated in criminal searches and seizures, ${ }^{165}$ cases finding a constitutional cause of action ${ }^{166}$ in a forced medical operation on a prisoner ${ }^{187}$ support the proposition that the body is protected by the fourth amendment in the medical as well as in the criminal context. The state's withholding of access to laetrile therefore intrudes upon an individual's legitimate expectation of dominion over his physical self.

A question arises, however, as to the extent of this interest in bodily integrity. There is a continuum of possible bodily intrusions; forcing a person to undergo unwanted treatment is the most excessive. In cases involving a patient's decision to refuse treatment, courts have found that the government's interests are not sufficiently compelling to justify infringement upon individual sovereignty. ${ }^{108}$ In contrast, the denial of a patient's free choice to

160 The right to control one's body is considered an essential element of personal autonomy, one of the basic reference points of the right of privacy. See Gerety, supra note 147, at 266 n.119. See generally Lister, The Right to Control the Use of One's Body, in The Rights of AMERrCANS 348 (1971).

161 See, e.g., Canterbury v. Spence, 464 F.2d 772 (D.C. Cir.), cert. denied, 409 U.S. 1064 (1972); Cobbs v. Grant, 8 Cal. 3d 229, 104 Cal. Rptr. 505, 502 P.2d 1 (1972); Wilkinson v. Vesey, 110 R.I. 606, 295 A.2d 676 (1972).

162211 N.Y. 125, 105 N.E. 92 (1914), overruled on other grounds, Bing v. Thunig, 2 N.Y.2d 656, 163 N.Y.S.2d 3, 143 N.E.2d 3 (1957), cited in People v. Privitera, 74 Cal. App. 3d 936, 948, 141 Cal. Rptr. 764, 770 (1977).

163 See Memorial Hospital v. Maxicopa County, 415 U.S. 250 (1974); cases involving prisoners' right to health care, cited in Questionable Drugs, supra note 51 , at $398 \mathrm{nn} .116-18$. It is an additional step, however, to say that the right not to be deprived of care includes a right to choose a particular type of care.

164 Schmerber v. California, 384 U.S. 757, 767 (1966) (mandatory blood tests of suspected drunk drivers permitted because highway safety can be viewed as compelling interest).

165 E.g., Terry v. Ohio, 392 U.S. 1 (1968); Katz v. United States, 389 U.S. 347 (1967); Schmerber v. California, 384 U.S. 757 (1966).

16642 U.S.C. $\$ 1983$ (1970).

167 Runnels v. Rosendale, 499 F.2d 733, 735 (9th Cir. 1974).

168 See, e.g., Cobbs v. Grant, 8 Cal. 3d 229, 104 Cal. Rptr. 505, 502 P.2d I (1972) (competent patient has right of bodily control and may choose whether to 
obtain and use any potential treatment regardless of its safety and efficacy appears to be a lesser intrusion. The right of bodily control is limited, ${ }^{169}$ and even intrusions that directly impinge upon the body have been upheld when the state has a sufficiently compelling interest. ${ }^{170}$

Another basis for finding a constitutional right to obtain and use laetrile, recognized by both Rutherford $\mathrm{V}$ and Privitera, is the protected nature of the doctor-patient relationship. Doe v. Bolton, ${ }^{171}$ one of the 1973 abortion cases, recognized a "woman's right to receive medical care in accordance with her licensed physician's best judgment, and the physician's right to administer it." ${ }^{172}$ In addition, Justice Douglas, concurring in Doe, stated that "[t]he right of privacy has no more conspicuous place than in the physician-patient relationship." 173 Further evidence of the Supreme Court's solicitude for the physician-patient relationship can be found in Whalen $v$. Roe, ${ }^{174}$ in which the Court, even though upholding a state statute that required the reporting of prescriptions for various drugs, noted in dictum that a patient and his advising

undergo lawful operation); In re Quinlan, 70 N.J. 10, 355 A.2d 647, cert. denied, 429 U.S. 922 (1976) (guardian of permanently comatose woman was permitted to enforce the woman's privacy right to be free of bodily intrusions by life-sustaining machines); Erickson v. Dilgard, 44 Misc. 2d 27, 252 N.Y.S.2d 705 (Sup. Ct. 1962) (competent patient allowed to decline blood transfusion despite risk of death). But see Application of President \& Directors of Georgetown College, Inc., 331 F.2d 1000 (D.C. Cir.), cert. denied, 377 U.S. 978 (1964) (court may allow hospital to administer emergency blood transfusion to unconsenting and arguably incompetent Jehovah's Witness).

100 [I]t is not clear to us that the claim ... that one has an unlimited right to do with one's body as one pleases bears a close relationship to the right of privacy previously articulated in the Court's decisions. The Court has refused to recognize an unlimited right of this kind in the past.

Roe v. Wade, 410 U.S. 113, 154 (1973) (citations omitied). See also Henkin, supra note 147, at 1429; Tribe, Toward a Model of Roles in the Due Process of Life and Law, 87 Harv. L. REv. 1, 39 (1973).

170 See, e.g., Roe v. Wade, 410 U.S. 113 (1973) (limitation on right of bodily control because of state interests in preserving health of mother, standards of medical practice, and life of viable fetus); Jacobson v. Mass., 197 U.S. 11 (1905) (limitation on right of bodily control in case of compulsory vaccination because of state health interest in preventing smallpox epidemic); Minnesota Board of Health v. City of Brainerd, 308 Minn. 24, 241 N.W.2d 624, appeal dismissed, 429 U.S. 803 (1976) (limitation on right of bodily control in case of fluoridation of city water supply, due to state interest in public health).

171410 U.S. 179 (1973).

172 Id. 197; accord, Roe v. Wade, 410 U.S. 113, 163 (1973).

173 Doe v. Bolton, 410 U.S. 179, 219 (1973) (Douglas, J., concurring). For a discussion of Justice Douglas' views on the right to privacy, see Privacy Opinions, supra note 147.

174429 U.S. 589 (1977). 
physician can independently decide to acquire and use needed drugs for personal health care. ${ }^{175}$

When a fundamental right to decide exists, a right of access to the means of effectuating that decision also exists. In Carey $v$. Population Services International, ${ }^{176}$ the Supreme Court clarified its decision in Eisenstadt $v$. Baird, ${ }^{177}$ by explicitly holding that the same strict scrutiny that is applied to statutes outlawing a protected choice must be applied to regulations that burden an individual's right to decide to use contraceptives or that limit his access to contraceptives. ${ }^{178}$ In the laetrile context, this holding means that a fundamental right to make the choice to use laetrile cannot be nullified by limiting access to the drug.

\section{Privacy Rights of Health Care Professionals}

Some courts have recognized an independent right of physicians to prescribe and treat patients "free from unjustified state interference." ${ }^{179}$ This independent right was recognized by the Privitera court as implicit in Doe v. Bolton. ${ }^{180}$

It is unlikely, however, that doctors have an independent right to administer any treatment they desire. First, "[i]t is . . . well settled that the State has broad police powers in regulating the administration of drugs by the health profession." 181 Second, the Supreme Court cases that have considered the right to administer treatment have always done so in the context of the right to receive it. $^{182}$ Indeed, the Court has suggested that doctor's independent

175 Id. 603.

176431 U.S. 678 (1977).

177405 U.S. 438 (1972).

178 The Court in Carey v. Population Services Int'l, 431 U.S. 678 (1977), explained that " $[t]$ his is not because there is an independent fundamental 'right of access ....; but because such access is essential to exercise of the constitutionally protected right of decision." Id. 688.

1 19 See, e.g., People v. Privitera, 74 Cal. App. 3d 936, 952-54, 141 Cal. Rptr. $764,773-74$ (1977).

$180 \leq 10$ U.S. 179, 197 (1973) (state statute requiring physicians other than the patients' own to approve an abortion infringed patients' right to receive medical treatment and doctors' right to administer it).

181 Whalen v. Roe, 429 U.S. 589, 603 n.30 (1977) (citations omitted). See also Robinson v. California, 370 U.S. 660, 664-65 (1962); Barsky v. Board of Regents, 347 U.S. 442,449 (1954).

182 See Whalen v. Roe, 429 U.S. 589 (1977); Doe v. Bolton, 410 U.S. 179 (1973); Roe v. Wade, 410 U.S. 113 (1973). The Court's decisions involving the health care interests of doctors have focused primarily on the standing aspect of this interest. Nevertheless, these cases delineate the substantive rights of physicians as well, acknowledging their right of privacy only in the context of patients' right to determine personal treatment. 
rights deserve less strict protection than the rights of their patients. ${ }^{183}$ Third, because the nature of medical practice is primarily economic, physicians' interests in health care may be subject to regulation as a commercial right. ${ }^{184}$ Other health care professionals, such as pharmacists and drug manufacturers, will probably also fail to prove any infringement upon their economic rights, because a low-level test will be applied to their complaints. ${ }^{185}$

Although there is no support for an independent right of doctors to administer particular drugs and treatments, the cases do support the existence of a derivative right. ${ }^{186}$ Moreover, on some occasions, courts relax the normal standing rules, and allow physicians to attack governmental drug regulations as violative of a patient's fundamental right to determine the nature of the treatment he is to receive. ${ }^{187}$

\section{Summary}

Supreme Court decisions dealing with health-care matters, bodily control, and the physician-patient relationship do not conclusively establish that personal health-care decisions are protected by the right of privacy. Nevertheless, several courts and commentators have concluded that a cancer patient's choice of medical treatment is entitled to strict constitutional protection. ${ }^{188}$ Therefore, this discussion of the constitutionality of the current laetrile regulations will proceed on the assumption that a cancer patient has a fundamental right to determine the method of his treatment,

183 See Whalen v. Roe, 429 U.S. 589, 604 n.33 (1977). The Court stated that Doe v. Bolton had not suggested that the physician's rights had "any greater strength than his patient's ... [i]f [those obstacles to obtaining an abortion in Doe v. Bolton] had merely made the physician's work . . . less independent without any impact on the patient, they would not have violated the Constitution." Id.

184 But see People v. Privitera, 74 Cal. App. 3d 936, 953, 141 Cal. Rptr. 764, 773 (1977) (" $t]$ he more recent cases hint at the more profound right in the doctor .... There exists in the doctor licensed to practice medicine a right constitutional in nature ... to treat ... an informed consenting patient.").

185 See Questionable Drugs, supra note 51, at 409.

186 See Whalen v. Roe, 429 U.S. 589 (1977).

187 The Supreme Court has extended to health care professionals standing to assert the rights of patients. See Eisenstadt v. Baird, 405 U.S. 438 (1972) (lecturer who distributed contraceptives); Griswold v. Connecticut, 381 U.S. 479 (1965) (physician and director of birth control clinic).

188 See generally Rutherford v. United States, 438 F. Supp. 1287 (W.D. Okla. 1977), aff'd as modified, No. 77-2049 (10th Cir. July 10, 1978) (not reaching constitutional issue), petition for cert. filed, 47 U.S.L.W. 3278 (U.S. Oct. 10, 1978) (No. 78-605); People v. Privitera, 74 Cal. App. 3d 936, 141 Cal. Rptr. 764 (1977); Freedom of Choice, supra note 128, at 216; Questionable Drugs, supra note 51, at 399; Comment, Restrictions on Unorthodox Health Treatment in California: A Legal and Economic Analysis, 24 U.C.L.A. L. Rev. 647, 680-89 (1977) [hereinafter cited as Unorthodox Treatment]. 
subject to governmental restriction only upon the demonstration of a compelling state interest.

\section{B. Government Interests in Prohibiting Laetrile}

The principal government interest in maintaining the current laetrile ban is the protection of the regulatory system instituted by Congress through the Food, Drug, and Cosmetic Act, to maintain a pre-marketing requirement of demonstrable safety and effectiveness and to ensure a scientific approach to drug testing. Preceding sections of this Comment established that laetrile is not marketable under the Act as it is presently written. ${ }^{189}$ As a result, an exception to the general requirements of proving safety and effectiveness threatens the survival of this aspect of the Act. Congress found that the public needs protection from drugs that have not been proven to be both safe and effective. ${ }^{190}$ It chose to implement this policy through the creation of new drug application procedures that place the burden of proof on drug producers. ${ }^{191}$

The present attacks on the Act by laetrile supporters go beyond the controversy surrounding that particular drug; if these attacks are successful, the government will not be able to force a manufacturer to prove a drug's safety and effectiveness before the manufacturer releases it to an unsuspecting public. Allowing laetrile to be marketed in an unproven condition, therefore, adversely affects the collective well-being by removing or weakening an important societal protection.

Although some commentators question the constitutionality of the drug efficacy requirements, ${ }^{192}$ the application of the statute has been upheld.193 Thus, the government has a compelling interest in preserving the standards of the Act. There are several interests implicit in the federal drug regulations, however, that can also be considered compelling. This Comment will examine these objectives more closely, in the specific context of the laetrile controversy.

\section{Protecting Individuals from Drugs of Unproven Safety}

A major governmental interest implicit in the establishment of the federal drug laws is the protection of both the general public

189 See text accompanying notes 23-135 supra.

$190 \mathrm{See} 21$ U.S.C. $\$ 355(\mathrm{e})(1976)$. For an explanation of congressional intent, see 1962 Senate Report, note 35 supta, [1962] U.S. Code Cong. \& AD. News 2884. 19121 U.S.C. $\$ 355$ (1976).

192 See, e.g., Freedom of Choice, supra note 128.

193 Weinberger v. Hynson, Wescott \& Dunning, Inc., 412 U.S. 609 (1973); Rutherford v. AMA, 379 F.2d 641 (7th Cir. 1967), cert. denied, 389 U.S. 1043, rehearing denied, 390 U.S. 975 (1968); Tutoki v. Celebrezze, 375 F.2d 105 (7th Cir. 1967). 
and specific individuals from dangerous drugs. ${ }^{104}$ The right to choose a particular health care treatment clearly is outweighed by the government's obligation to prevent damage to the general public, as evidenced in the thalidomide crisis, and by the need to prevent an individual's self-destruction through ingestion of a hazardous substance. The government, therefore, faces no constitutional obstacle in limiting the availability of decidedly unsafe drugs. The regulation of drugs of uncertain danger, however, is more problematic.

As has previously been discussed, ${ }^{195}$ the latest scientific evidence indicates that laetrile is not safe, ${ }^{196}$ but its danger has not been established conclusively. While the evidence suggesting that laetrile is not safe gives the government a legitimate interest in its regulation, the important question is whether the probability and gravity of its dangers are sufficiently substantial to make this interest compelling.

Recorded instances ${ }^{197}$ of death and poisoning from laetrile show that the gravity of the harm is substantial. Present knowledge does not indicate, however, that the probability of the harm is also great. First, so far as is known, only a small number of persons have actually sustained injury from use of the drug. Second, there is no evidence indicating that adverse side effects occur more frequently with laetrile use than with other medical treatments. ${ }^{198}$

The government's interest in protecting the populace from unsafe drugs may not be compelling at this time in the case of laetrile; the mounting evidence of laetrile's dangers, however, may make it compelling in the future. Other interests implicit in the federal regulations must therefore be found to justify an infringement of personal autonomy.

\section{Preventing the Delay of Effective Treatment}

A second state interest in the regulation of unproven drugs is the protection of the public from the use of ineffective drugs. Reliance upon an ineffective drug can be deterimental to a patient's

194 See Picking Your Poison, supra note 148, at 608-09.

195 See text accompanying notes 83-92 supra.

196 See notes 84-86 supra.

187 Id.

188 Studies show that many patients die or suffer detrimental side effects due to incompetent doctoring and unexpected reactions to medication when treated for various illnesses. See, e.g., Incompetent Surgery Is Found Not Isolated, N.Y. Times, January 27,1976 , at 1 , col. 7 . 
interests by preventing or delaying his use of an effective treatment. ${ }^{199}$

The possibility that patients will rely on laetrile to the exclusion or delay of conventional therapy has been a matter of concern to the FDA and the medical establishment. ${ }^{200}$ Several courts have upheld the proscription of laetrile on this basis, and accepted the need to prevent delay of effective treatment as a substantial government objective. ${ }^{201}$ This interest assumes, however, that cancer can be treated effectively by other drugs or methods. ${ }^{202}$

As previously established, although there is no cure for cancer, certain treatments can effectively treat particular types of cancer and either prevent, delay, or ameliorate its attendant infirmities. ${ }^{203}$ Removing the laetrile ban would surely result in some cancer patients deliberately foregoing a more effective treatment. Such behavior reasonably may be classified as self-destructive, ${ }^{204}$ and the government's interest in preventing such a result is compelling.

199 See Durovic v. Richardson, 479 F.2d 242, 250 (7th Cir.), cert. denied, 414 U.S. 944 (1973) (in case of life-threatening disease, "safe" necessarily implies "effective"); United States v. Nutrition Service, Inc., 227 F. Supp. 375, 388 (W.D. Pa. 1964), aff'd, 347 F.2d 233 (3d Cir. 1965). Cf. 17 Cas. Ad. Cone $\$ 10400.1$ (1963) (California Health Department ruled that ineffective cancer remedies such as laetrile are more harmful than state-sanctioned alternatives).

200 See 42 Fed. Reg. 39,767, 39,769 (1977); Laetrile Myth, supra note 85, at 8-9 (physician's case history of laetrile user who failed to seek conventional treatment and died needlessly).

201 See, e.g., United States v. General Research Laboratories, 397 F. Supp. 197, 199 (C.D. Cal. 1975) (explicitly finding delay to be dangerous); People v. Privitera, 55 Cal. App. 3d 39, 52, 128 Cal. Rptr. 151 (1976), rev'd, 74 Cal. App. 3d 936, 141 Cal. Rptr. 764 (1977).

202 See Questionable Drugs, supra note 51, at 401.

203 See note 132 supra.

204 Contra, Rutherford v. United States, 438 F. Supp. 1287, 1299 n.25 (W.D. Okla. 1977), aff'd as modified, No. 77-2049 (10th Cir. July 10, 1978), petition for cert. filed, 47 U.S.L.W. 3278 (U.S. Oct. 10, 1978) (No. 78-605). The court explained that refusing orthodox treatment is not suicidal because there have been reported cases of untreated cancer victims outliving treated ones. The court also stressed the unpleasant nature of conventional remedies. This last point may explain why a patient would choose to forego conventional treatment, but it does not alter the fundamental self-destructiveness of the act. When a person passes up a chance of recovery, either to use a totally ineffective remedy or even to use no remedy at all, there is a chance that this decision will not be harmful. On the whole, however, such a decision evidences a lack of concern for one's safety that may be vitiated by government intervention.

Not all self-destructive acts are regulable. When a patient refuses to submit to treatment altogether, courts may find that there is no government interest compelling enough to force treatment. See In re Osborne, 294 A.2d 372, 374 (D.C. 1972). There is quite a difference, however, between forcing someone to take a treatment they wish to refuse, and refusing to allow a patient to use a drug that will do them no good. The latter is a much lesser restriction on individual liberty, and has fewer corollary effects on persons other than the patient. See text accompanying note 205 infra. 
There is an additional component to the interest in preventing the delay of effective treatment, which increases its constitutional significance: the use of laetrile affects patients other than those who knowingly choose to use an ineffective treatment. The removal of the ban for these patients inevitably legitimizes the drug's use by the general public. ${ }^{205}$ As a result, other, less knowing, patients will also be induced to use laetrile rather than a more effective treatment, thereby threatening the collective welfare of the community.

\section{Preventing Deception of the Public}

The third major component of federal drug regulation is protecting the drug-consuming public from misleading claims of effectiveness. ${ }^{206}$ Cancer has a devastating effect on the emotions and outlook of the victim and his family. Moreover, cancer patients are particularly vulnerable to exploitation because they face an uncertain probability of recovery and treatment methods that impose acute emotional and physical difficulties. ${ }^{207}$ Because patient vulnerability has been exploited many times in the past, ${ }^{208}$ the government is wary of alleged cancer cures. This legitimate concern gives the government an interest in ensuring that drugs made available as cancer treatments have met certain effectiveness standards. Laetrile has not been able to meet these standards.

Some aspects of the manner of laetrile's promotion add greater credence to the government's fear of public exploitation. The drug is "sold" at conventions, meetings, and private gatherings through the employment of testimonials, films, and books. ${ }^{209}$ In addition, some laetrile promoters have made extremely questionable medical claims-namely, that the drug is an essential new vitamin (vitamin

205 Carnohan v. United States, No. 77-0010-GT, slip op. at 3 (S.D. Cal., filed Jan. 21, 1977). To weaken the existing drug laws "could also further the growing tendency of those afflicted with this disease to engage in self treatment resulting in a delay in seeking early diagnosis and prompt treatment with forms of therapy that have established value." Id. (quoting Morgan v. Mathews, No. 76-1637 (S.D. Cal., filed Nov. 30, 1976)). See generally Picking Your Poison, supra note 148, at 613-14. 206 Because the majority of major cancer studies express doubt that laetrile cures or mitigates the disease, this Comment treats such claims for laetrile as misleading.

20742 Fed. Reg. 39,767, 39,798 (1977).

208 See People v. Privitera, 74 Cal. App. 3d 936, 979-80, 141 Cal. Rptr. 764, 791 (1977) (dissenting opinion); 42 Fed. Reg. 39,767, 39,795-97 (1977); Janssen, supra note 2, at 27-32; Quack Laws, supra note 2, at 402 . In each decade of the twentieth century there have been alleged miracle cancer drugs and treatments that have been heavily promoted to the financial and emotional detriment of the public. All of these alleged remedies-Millure, Krebiozen, Rand Vaccine, Hoxsey method, Koch Antitoxins, and Doctor Johnson's Treatment-proved to be totally ineffective.

20942 Fed. Reg. 39,767, 39,799-800 (1977). 
B17) and is an effective treatment for all types of cancer. ${ }^{210}$ The history of drug fraud in the United States and the unproven nature of laetrile's effectiveness, coupled with the extravagant claims of some of its supporters, demonstrate that laetrile poses a potential threat to the well being of cancer patients. ${ }^{211}$ In the absence of an effective system of public disclosure, the government's interest in preventing deception can be classified as substantial.

\section{Less Restrictive Alternatives}

The preceding analysis demonstrates that the government's justification for maintaining the current regulatory scheme encompasses several interests, which, in the aggregate, are compelling. It remains to be seen, however, whether these interests are applicable to all classes of patients, or whether there are less restrictive means to effectuate these objectives. When fundamental rights are at stake, government interests need not only be compelling; they must also be necessary. ${ }^{212}$ If other methods can achieve these governmental interests with a lesser impact on individual rights, the more restrictive method fails to satisfy constitutional standards. ${ }^{213}$

\section{A Spectrum of Interests}

The articulated governmental interests in controlling the use of laetrile are particularly compelling in the case of a new cancer patient who has the greatest chance of recovery through conventional treatment. The question arises, however, whether these interests are equally compelling for all classes of cancer patients. The distinction drawn by the Rutherford VI court ${ }^{214}$ between terminally-ill and nonterminally-ill patients, for example, could be constitutionally mandatory. ${ }^{215}$

210 Id. 39,801-03. See Janssen, supra note 2, at 30.

211 Laetrile is also detrimental to the financial well-being of its users since the drug is very expensive, both in the United States and at foreign clinics. See Lewis, supra note 3 , at 61 ; N.Y. Times, July 13, 1977, at 8, col. 4; N.Y. Times, April 17, 1977, at 28, col. 1 .

212 Roe v. Wade, 410 U.S. 113, 155 (1973).

213 The Court has often used a "least restrictive means" test. See, e.g., Shelton v. Tucker, 364 U.S. 479, 487-90 (1960). "[E]ven though the governmental purpose be legitimate and substantial, that purpose cannot be pursued by means that broadly stifle fundamental personal liberties when the end can be more narrowly achieved." Id. 488 .

214 No. 77-2049, slip op. at 4-5 (10th Cir. July 10, 1978), petition for cert. filed, 47 U.S.L.W. 3278 (U.S. Oct. 10, 1978) (No. 78-605). See notes 128-35 supra \& accompanying text.

215 See Freedom of Choice, supra note 128, at 220; Picking Your Poison, supra note 148 , at 615-16. 
The government's interests in prohibiting the use of laetrile by terminal patients are arguably less compelling for two reasons. First, decisions regarding one's death appear to constitute a higher order of privacy than general health care decisions; the right to die as one wishes, in circumstances in which there is no hope of eventual recovery, is closer to the right to decide matters of procreation and marital intimacy than is the decision to choose one treatment over another. ${ }^{218}$ Second, self-destructive behavior seems less objectionable when a patient is terminally ill.

This distinction is not justified. Even if the privacy rights of the terminally ill are more fundamental, the government's interests in regulating unproven drugs are compelling. The points made earlier about the fallacies in the Rutherford VI opinion regarding the terminally ill remain valid. ${ }^{217}$ There often is no reliable distinction between terminal and non-terminal patients. ${ }^{218}$ Potentially aidable patients should not be cast aside. It is also untrue that the use of laetrile by the terminally ill is not self-destructive behavior. The scientific evidence establishes that laetrile is essentially useless for everyone, ${ }^{219}$ but other treatments provide some hope of prolonging life, even for those patients classified as terminal.220

The government's interests remain compelling ${ }^{221}$ even if the problems created by an exception for the terminally ill are deemed insignificant. The use of laetrile by any particular group may increase instances of fraud and encourage other patients to forego difficult conventional treatment for easy laetrile therapy.222 There is a grave potential for abuse when supplies of an otherwise illegal and ineffective drug are made available for use by an ill-defined class of patients.

Some commentators have suggested that laetrile be provided as a supplemental treatment.223 The government theoretically could have a compelling interest in preventing the exclusive use of the drug, without being able constitutionally to regulate its supple-

216 Compare In re Quinlan, 70 N.J. 10, 355 A.2d 647 (1976) (right of privacy includes right to refuse extraordinary medical procedures to maintain life where patient is in a vegetative state) with Fitzgerald v. Porter Memorial Hospital, 523 F.2d 716 (7th Cir. 1975), cert. denied, 425 U.S. 916 (1976) (no right of privacy violated when public hospital denied couple opportunity to use Lamaze method of childbirth).

217 See notes 130-33 supra \& accompanying text.

21842 Fed. Reg. 39,767, 39,779 (1977); Laetrile Myth, supra note 85, at 8. 210 See notes 101-35 supra.

220 Laetrile Myth, supra note 85, at 5-6.

221 See, e.g., 42 Fed. Reg. 39,767, 39,805 (1977).

222 Laetrile Myth, supra note 85, at 8.

223 See, e.g., Questionable Drugs, supra note 51, at 407. 
mental use. The government does, however, have compelling interests in preventing this alternative.

Initially, this exception to the general regulation of laetrile exposes the patient to potentially greater risks. The effects of combined laetrile and conventional therapy are unknown and are not easily ascertainable.224 Concurrent use of laetrile may interfere with the beneficial effects of conventional methods or create new dangers. In addition, this alternative would provide laetrile with a perceived legitimacy, through the widespread distribution and use of the drug. Supplemental use of laetrile would pose administrative problems as well, and hamper the government's ability to enforce the remaining aspects of the laetrile prohibition.

\section{Fundamental Statutory Changes}

The continued ban on laetrile is mandated by compelling governmental interests for all classes of patients and degrees of use. However, a closer examination must be made of suggested alternative procedures that may further these governmental interests with a lesser infringement of individual rights.

One suggested alternative is to eliminate the efficacy requirement of the Act and replace it with a strict reporting and disclosure provision. ${ }^{225}$ Unsafe drugs would continue to be prohibited, and a drug's degree of effectiveness would have to be displayed prominently on its label. The FDA would also maintain its power over misbranded and falsely-labeled drugs. Under this system, the drugconsuming public, aided by consumer studies, label disclosures, and scientific data, would be expected to distinguish between valuable medicine and well-promoted, but useless, substances. The medical profession would also be available to guide consumer choices.

Another alternative is to shift the threshold standard of proof for proposed new drugs and established old ones. Instead of requiring affirmative proof of a drug's actual or recognized safety and effectiveness before permitting marketing, Congress could force the government to prove actual danger or ineffectiveness in order to prohibit a drug. ${ }^{228}$

22442 Fed. Reg. 39,767, 39,805 (1977). Proper study of the effects of drug interaction is time consuming. The continuing public debate over laetrile's safety and effectiveness suggests that the probability of harm from the concurrent use of laetrile would be equally difficult to determine.

225 See Freedom of Choice, supra note 128, at 222; Questionable Drugs, supra note 51, at 408; Unorthodox Treatment, supra note 188, at 694 .

226 See Unorthodox Treatment, supra note 188, at 694. One proposal, introduced in the 95th Congress, would eliminate the effectiveness standard from the Act and use the FDA's authority over misbranded drugs to monitor the accuracy of 
Although these alternatives would indeed reduce the extent of the government's interference with privacy rights, they are not acceptable replacements for the current regulatory procedures. Each of them fails to satisfy the compelling governmental interests that underly the need for drug regulation. First, they do not adequately protect the interest in safeguarding the public. Individuals could suffer serious physical harm from the placement of untested products on the market. Putting the burden on the government is not satisfactory: the government does not have the resources to evaluate each drug product created and marketed by pharmaceutical companies. Neither of these proposals furthers the government's interest in preventing the delay of effective treatment. In addition, these proposals fail because the public, including individual physicians, has neither the expertise nor the time to distinguish between various drugs and medications. People might use a totally ineffective drug without being fully aware of the consequences. Finally, and perhaps most importantly, these proposals remove the rigid scientific standards of the present Act. This change would increase the likelihood of fraud and quackery. Thus, the adoption of these alternatives or similar proposals would reestablish the impotent regulatory schemes of past decades and leave the public virtually defenseless in the field of health care.

\section{CONCLUSION}

The laetrile controversy stands at the junction of two important and conflicting interests. One is the alleged fundamental privacy right of patients to choose, obtain, and use desired health care drugs. The other is the government's compelling interest in preserving the structure of the federal drug laws and preventing self-destructive individual behavior or conduct seriously threatening the health, safety, and welfare of its citizens.

The difficult task of reconciling these important interests poses a significant challenge to judicial and political institutions. The resolution of the dilemma, however, is clear. The courts, Congress, and the state legislatures should reaffirm federal drug policy and its application to laetrile. By continuing to prohibit laetrile, the FDA can deter some cancer patients from relying upon a potentially devastating drug and encourage them to seek effective treatment within the confines of the medical establishment.

claims made by their backers. See H.R. 54, 95th Cong., 2d Sess., reprinted in 123 Cong. REC. 79 (1977). 
This Comment has supported the prohibition of laetrile on both statutory and constitutional grounds. Laetrile is not generally recognized as safe or effective by cancer experts and it cannot justifiably be exempted from the provisions of the Food, Drug, and Cosmetic Act. As a result, the FDA should seek reversal of the Rutherford VI decision, and should continue to ban laetrile from commercial or personal transportation in interstate commerce, even when it is sought for use by terminally-ill cancer patients. Similarly, a weighing of constitutional values dictates the prohibition of laetrile and the reaffirmation of the FDA's safety and effectiveness requirements. The use of laetrile threatens compelling interests and legitimate governmental policies. These societal interests ultimately outweigh individual privacy interests in health care and necessitate an infringement upon individual sovereignty. 